\title{
Natural products: a hope for glioblastoma patients
}

Review

\author{
Raghupathy Vengoji ${ }^{1}$, Muzafar A. Macha ${ }^{1,2}$, Surinder K. Batra ${ }^{1,3}$ and Nicole A. \\ Shonka ${ }^{3,4}$ \\ ${ }^{1}$ Department of Biochemistry and Molecular Biology, University of Nebraska Medical Center, Omaha, NE, 68198, USA \\ ${ }^{2}$ Department of Otolaryngology/Head and Neck Surgery, University of Nebraska Medical Center, Omaha, NE, 68198, USA \\ ${ }^{3}$ Eppley Institute for Research in Cancer and Allied Diseases and Buffett Cancer Center, University of Nebraska Medical \\ Center, Omaha, NE, 68198, USA \\ ${ }^{4}$ Department of Internal Medicine, Division of Oncology and Hematology, University of Nebraska Medical Center, Omaha, NE, \\ 68198, USA \\ Correspondence to: Nicole A. Shonka, email: nshonka@unmc.edu \\ Surinder K. Batra, email: sbatra@unmc.edu
}

Keywords: glioblastoma; temozolomide; blood brain barrier and chemotherapeutic drugs

Received: February 14, $2018 \quad$ Accepted: March 28, $2018 \quad$ Published: April 24, 2018

Copyright: Vengoji et al. This is an open-access article distributed under the terms of the Creative Commons Attribution License 3.0 (CC BY 3.0), which permits unrestricted use, distribution, and reproduction in any medium, provided the original author and source are credited.

\section{ABSTRACT}

Glioblastoma (GBM) is one of the most aggressive malignant tumors with an overall dismal survival averaging one year despite multimodality therapeutic interventions including surgery, radiotherapy and concomitant and adjuvant chemotherapy. Few drugs are FDA approved for GBM, and the addition of temozolomide (TMZ) to standard therapy increases the median survival by only $\mathbf{2 . 5}$ months. Targeted therapy appeared promising in in vitro monolayer cultures, but disappointed in preclinical and clinical trials, partly due to the poor penetration of drugs through the blood brain barrier (BBB). Cancer stem cells (CSCs) have intrinsic resistance to initial chemoradiation therapy (CRT) and acquire further resistance via deregulation of many signaling pathways. Due to the failure of classical chemotherapies and targeted drugs, research efforts focusing on the use of less toxic agents have increased. Interestingly, multiple natural compounds have shown antitumor and apoptotic effects in TMZ resistant and p53 mutant GBM cell lines and also displayed synergistic effects with TMZ. In this review, we have summarized the current literature on natural products or product analogs used to modulate the BBB permeability, induce cell death, eradicate CSCs and sensitize GBM to CRT.

\section{INTRODUCTION}

Tumors of the central nervous system (CNS) represent $1.4 \%$ of all newly diagnosed cancers and $2.6 \%$ of cancer deaths in 2015 [1]. Although rare, they are a significant cause of cancer morbidity and mortality and account for $30 \%$ and $20 \%$ of cancer related deaths in children and young adults respectively [1]. Brain tumors account for $85 \%-90 \%$ of all primary CNS tumors. Glioblastoma (GBM) accounts for approximately half of all malignant adult brain tumors and is associated with the shortest survival [2]. Multimodality therapeutic intervention including surgery followed by adjuvant chemoradiation therapy (CRT) with temozolomide
(TMZ), a DNA alkylating agent, is the standard of care for GBM. The addition of TMZ increased the overall survival (OS) from 7.7 to 13.5 months and from 7.9 to 10.0 months in the GBM patients with methylated and non-methylated $\mathrm{O}^{6}$-methylguanine-DNA methyl transferase (MGMT) respectively [3, 4]; however survival remains very poor. This poor survival is likely a product of many factors, including systemic toxicity of higher TMZ doses, BBB impermeability, resistance to CRT and development of refractory tumors [5]. Therefore, there is a crucial need for identifying novel compounds that are able to modulate the $\mathrm{BBB}$, inhibit tumor growth and prevent development of recurrent tumors for improved overall patient prognosis. 
In the last two decades, natural product based therapy has gained popularity as effective and potentially less toxic treatment. Roots of Podophyllum peltatum (mayapple) were used by the American Indians long ago to treat many skin cancers [6]. The principal anticancer constituent podophyllotoxin and its semisynthetic derivatives, namely Teniposide, Etoposide and Etopophos are extensively used to treat several cancers [7]. The National Cancer Institute (NCI) initiated two mega- scale anti-cancer drug-screening programs during 1960 and 1985. From that screening, they identified an important compound Taxol (paclitaxel), isolated from the bark of Taxus brevifolia that has since been used to treat many solid tumors. Moreover, nearly onethird of the drugs approved by the United States Food and Drug Administration (USFDA) for cancer are from natural products or their analogs $[6,8]$. We have summarized the published literature on natural products and their analogs that have been used to treat GBM using in vitro and in vivo models. In addition, we also discuss the utility of many natural compounds including procyanidine and scillarenin in modulating the BBB to improve drug delivery and enhance therapeutic efficacy.

\section{NATURAL PRODUCTS AND GBM}

GBM represents a highly invasive and highly heterogeneous type of malignant brain tumor [9]. Detailed molecular analysis of GBM reveals dysregulation of core signaling pathways including those that regulate cell growth, DNA repair and apoptosis like receptor tyrosine kinase (RTK), phosphoinositide 3-kinase (PI3K) signaling, mitogen activated protein kinase (MAPK) signaling, retinoblastoma and p53 signaling [9]. In addition, $30-40 \%$ of GBM patients have mutations in the tumor suppressor gene TP53 [10] resulting in chemo- and radioresistance. TP53 encodes for p53, a transcription factor known to regulate multiple functions such as DNA repair, cell cycle arrest, senescence, apoptosis and metabolism. Haas-Kogan et al., observed increased radio-resistance to fractionated radiation therapy (RT) in GBM cells expressing mutated p53 [11], while transduction of wild type p53 in the 9L GBM cell line increased sensitivity to cisplatin [12]. Although TMZ is BBB permeable and is less myelotoxic than other drugs available for GBM [13], unfortunately, mutant TP53 confers TMZ resistance by up-regulating MGMT expression in T98G and U138 GBM cell lines [14]. While TMZ induces DNA damage by methylating the $\mathrm{O}^{6}$ position of the guanine base in DNA, active MGMT (22 $\mathrm{kDa}$ protein) rapidly removes methyl groups than other alkyl groups linked to the $\mathrm{O}^{6}$ position of guanine [15] and directly repairs the TMZ-damaged DNA [16]. Although the current TMZ based CRT has marginally improved survival in MGMT methylated (ie MGMT inactivated) GBM patients, its cytotoxicity is relatively nullified in unmethylated GBM patients [17]. Recent, recent analysis of quantitative methylation using pyrosequencing on $108 \mathrm{GBM}$ patients revealed that degree of MGMT promoter methylation is directly associated with median progression free survival [18]. Currently, small molecule inhibitors targeting MGMT are being utilized prior to TMZ based therapy in many clinical trials [19]. In addition, research is focused to identify minimally toxic compounds that are able to target novel deregulated signaling pathways, evade the $\mathrm{BBB}$, and enhance therapeutic efficacy. Plant based products have long been used to influence cancer development, progression, and metastasis. A number of studies have revealed the antitumor potential of natural compounds used either alone or in combination with chemotherapy (CT) and RT in GBM and are summarized below.

\section{Natural products as chemosensitizers in GBM}

The efficacy of CRT for GBM is limited by poor drug availability, treatment toxicity, and chemoradiation resistance. Natural products and product analogs with potential as chemo/radio sensitizers in GBM are summarized in Table 1.

\section{Quercetin}

Cancer induced inflammation can accelerate tumor cell proliferation, survival and migration. Interleukin-6 (IL6 ) is the primary cytokine which creates the inflammatory peri-tumoral environment. Its increased expression in GBM [20] is directly associated with poor patient survival [21]. In addition, persistent activation of Signal Transducer and Activator of Transcription - 3 (STAT3) by autocrine expression of IL- 6 is observed in GBM cell lines. Scavenging of IL-6 using specific antibodies repressed cell proliferation and stimulated apoptosis [22]. Quercetin, a natural flavonoid ubiquitously present in various vegetables and fruits including broccoli, red onions, apples, red grapes, cherries and berries [23] has been identified as an antioxidant and anticancer agent [24-26]. Specific to GBM, Jonathan et al., showed that quercetin treatment significantly decreased the IL-6 mediated STAT3 activation in U87 and T98G cell lines in a concentration dependent manner [27]. This flavonoid also increased the sensitivity of GBM lines U87 and U251 to TMZ by suppressing heat shock protein 27 (Hsp27) expression, that is known to confer drug resistance [28]. Additionally, quercetin has also been shown to induce mitochondria mediated apoptosis in the resistant p53 mutant GBM cell line U373MG [29]. In contrast to these anti-tumorigenic properties of Quercetin, pro-tumorigenic effects of Quercetin were also reported in a rat glioma model [30].

\section{Resveratrol}

Resveratrol is a potent anti-oxidant found in grapes, peanuts and mulberries [31] with known anti-tumor activity [31]. Huang et al., demonstrated that resveratrol treatment 
Table 1: Natural products and product analogs with potential as chemo/radio sensitizers in GBM

\begin{tabular}{|c|c|c|c|c|}
\hline S. No & Scientific Name & Component & Function & Refs \\
\hline 1 & Allium сера & Quercetin & $\begin{array}{l}\downarrow \text { Hsp27 and } \uparrow \mathrm{TMZ} \text { sensitivity in U87 and } \\
\mathrm{U} 251 \text { GBM cell lines }\end{array}$ & [28] \\
\hline 2 & Vitis vinifera & Resveratrol & $\begin{array}{l}\downarrow \text { MGMT expression, } \downarrow \text { Nf-KB signaling and } \downarrow \\
\text { antiapoptotic proteins XIAP and survivin and } \\
\uparrow \text { TMZ sensitivity in T98G GBM cells }\end{array}$ & [32] \\
\hline 3 & Vitis vinifera & Resveratrol & $\begin{array}{l}\uparrow \text { ROS generation, } \uparrow \text { AMPK activation }, \downarrow \\
\text { mTOR signaling }, \downarrow \text { antiapoptotic protein Bcl-2 } \\
\text { and } \uparrow \text { TMZ sensitivity in SHG44 GBM cells; } \\
\downarrow \text { orthotopic GBM xenograft with TMZ }\end{array}$ & {$[33]$} \\
\hline 4 & Herba Epimedi & Icariin & $\begin{array}{l}\downarrow \text { proliferation of U87 GBM cells; } \downarrow \text { Nf-KB } \\
\text { signaling, } \downarrow \text { migration, } \downarrow \text { invasion and } \uparrow \mathrm{TMZ} \\
\text { sensitivity in U87 GBM cells }\end{array}$ & [37] \\
\hline 5 & Ficus carica & Latex & $\begin{array}{l}\downarrow \text { proliferation of U87, U138MG and T98G } \\
\text { GBM cell lines; } \uparrow \text { tumor suppressor let- } \\
\text { 7miRNA, } \downarrow \text { invasion and } \uparrow \mathrm{TMZ} \text { sensitivity }\end{array}$ & {$[42]$} \\
\hline 6 & Apis mellifera & $\begin{array}{l}\text { Ethanolic extract of } \\
\text { Propolisis }\end{array}$ & $\begin{array}{l}\downarrow N f-K B \text { signaling and } \uparrow \mathrm{TMZ} \text { sensitivity in U87 } \\
\text { GBM cells }\end{array}$ & {$[43]$} \\
\hline 7 & Apis mellifera & Propolisis & $\begin{array}{l}\downarrow \text { cell proliferation in U343 and U251 GBM cell } \\
\text { lines, } \uparrow \text { chemosensitivity to TMZ }\end{array}$ & [49] \\
\hline 8 & Zataria multiflora & $\begin{array}{l}\text { Hydroalcoholic } \\
\text { extract }\end{array}$ & $\uparrow$ radiosensitivity of A172 GBM cells & {$[86]$} \\
\hline 9 & $\begin{array}{l}\text { Stephania } \\
\text { tetrandra } \text { S. Moore }\end{array}$ & Tetrandrine & $\begin{array}{l}\uparrow \mathrm{G}_{0} / \mathrm{G}_{1} \text { cell cycle arrest; } \downarrow \text { radiation induced } \\
\text { ERK signaling and proliferation associated } \\
\text { genes PCNA and CCND1; } \uparrow \text { radiosensitivity of } \\
\text { U87 and U251 cell lines }\end{array}$ & {$[88]$} \\
\hline 10 & Withania somnifera & Withaferin A & $\begin{array}{l}\downarrow \text { cell proliferation of U87, U251 and TMZ } \\
\text { resistant GBM cell lines U87 TMZ, U251 TMZ, } \\
\text { T98G and U138 in a concentration dependent } \\
\text { manner, } \uparrow \mathrm{TMZ} \text { sensitivity by } \downarrow \text { MGMT } \\
\text { expression. }\end{array}$ & {$[53]$} \\
\hline 11 & Curcuma longa & Turmeric Force ${ }^{\mathrm{TM}}$ & $\uparrow$ sensitivity to TMZ in U87 GBM cells & {$[204,205]$} \\
\hline
\end{tabular}

significantly decreased TMZ resistance by downregulating the expression of MGMT, at least in part through NF-KB dependent signaling in T98G GBM cells [32] (Figure 1). It also significantly decreased the expression of the anti-apoptotic proteins, X-linked inhibitor of apoptosis protein (XIAP) and survivin [32]. Another study showed that resveratrol increased TMZ toxicity by increasing reactive oxygen species (ROS) generation, AMPK pathway activation, mTOR signaling inhibition and decreased antiapoptic protein $\mathrm{Bcl}-2$ expression in SHG44 GBM cells [33]. Furthermore, combination treatment of resveratrol with TMZ also significantly reduced the orthotopic xenograft growth of GBM cells [33].

\section{Icariin}

Icariin is a flavonoid extracted from the Chinese medical herb Herba Epimedi. Icariin is known to have cardio-protective, anti-inflammatory, bone-healing, anti- depressant, neuro-protective and anti-cancer properties with low toxicity $[34,35]$. It is believed to cross the BBB [36] and therefore can be more available to the tumor cells. Lijuan et al., identified that icariin treatment significantly decreased the growth of U87 GBM cells in a concentration dependent manner [37]. He further showed that Icariin augments the cytotoxicity of TMZ and decreased the migration and invasion of U87 GBM cells probably by attenuating NF-KB activity [37].

\section{Latex and resins}

MicroRNAs (miRNAs) are small non-coding RNA molecules that regulate gene function during transcription and translation and play both pro- and anti-tumorigenic roles. Let-7 miRNA is one of the important miRNAs that suppress tumor growth and is downregulated in many cancers [38-40]. Overexpression of Let-7 sensitized 
cancers to the chemotherapeutic agent cisplatin [41]. Recent studies have shown that latex from the Ficus carica, a member of the mulberry family significantly inhibited the proliferation of U87, U138MG and T98G cells by upregulating let-7 expression [42]. Furthermore, it attenuated cell invasion and induced TMZ sensitivity by upregulating let-7 expression [42]. Propolis resin from the honeybee is comprised of flavonoids, steroids, terpenes, vitamins (B1, B2, C and E), esters and sugars [43]. While propolis is well documented to have antibacterial, antiviral, antifungal, and immunomodulatory functions [44-47], a recent study showed anti-cancer activities from its flavonoid components [48]. Kleiton et al., showed that propolis decreased the proliferation of U343 and U251 GBM cells and human lung fibroblast cell line MRC5 [49]. More interestingly, they showed a synergistic antiproliferative effect of propolis in combination with TMZ in GBM cells [49]. Renata et al. also demonstrated that an ethanolic extract of propolis in combination with TMZ inhibited the growth of U87 cells [43]. Finally, they showed that the antiproliferative effect of propolis was due to NF-KB [43] inhibition, which is known to play a vital role in GBM [50].

NF-KB signaling may alter TMZ sensitivity [32, 37, 43], at least in part by downregulating MGMT expression [32]. The regulation of NF-KB and its activity is mainly controlled by $\mathrm{PI} 3 \mathrm{~K} / \mathrm{AKT}$ signaling [51, 52]. Interestingly, the natural compound Withaferin $\mathrm{A}$ mediated MGMT downregulation and the resultant TMZ sensitivity was associated with inhibition of the EGFR/ AKT/mTOR signaling pathway [53]. Surprisingly, PI3K/ AKT signaling has also been shown to play a vital role in GBM radioresistance $[54,55]$. Plant derived products known to inhibit PI3K/AKT signaling pathways may be used as a chemo- and radio- sensitizers are summarized below.

\section{Bittersweet}

Celastrus orbiculatus, commonly known as bittersweet belongs to the Celastraceae family and is used as a folk medicine to treat numerous diseases including

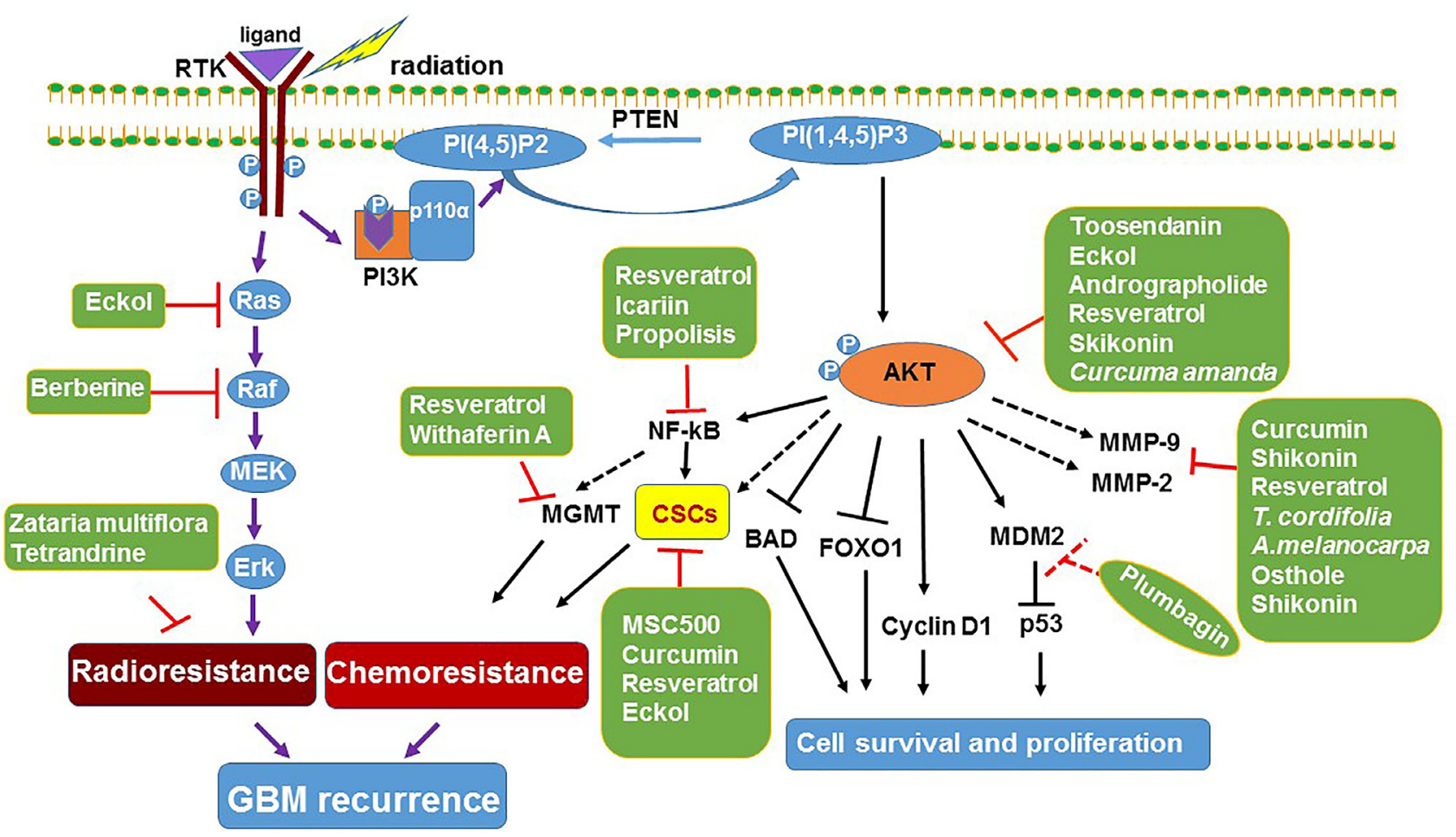

Figure 1: Mechanism of natural product based sensitization of GBM. RTKs activate Ras/Raf/MAPK signaling cascade to increase GBM cell proliferation. The RTK/PI3K/AKT signaling pathway inhibits apoptosis by phosphorylating the pro-apoptotic protein BAD resulting in its cytoplasmic sequestration to inhibit cytochrome-C release from mitochondria. It also inactivates the transcription factor FOXO1 by phosphorylation, resulting in inactivation of pro-apoptotic proteins and cell survival. Natural products resveratrol and eckol attenuate both the Ras/Raf and PI3K/AKT signaling pathways, inhibit cell proliferation, induce apoptosis and also eradicate GBM CSCs; Korean natural medicine recipe, MSC500 decreases CSCs population by decreasing the aldehyde dehydrogenase (ALDH) activity and downregulated the expression of $\mathrm{ABC}$ transporters (ABCG2 and $\mathrm{ABCB} 5$ ). Moreover, natural products especially resveratrol and Withaferin A increased the TMZ sensitivity by downregulating MGMT expression. Zataria multiflora hydroalcoholic extract and tetrandrine significantly increased the radiosensitivity of the GBM cell lines. RTK, receptor tyrosine kinase; MAP, mitogen- activated protein kinase; CSCs, cancer stem cells; PTEN, phosphatase and tensin homolog; MGMT, $\mathrm{O}^{6}$-methylguanine-DNA methyl transferase; PI $(4,5) \mathrm{P} 2$, phosphatidylinositol-4,5-bisphosphate; PI $(1,4,5)$ P3 - phosphatidylinositol-3,4,5-trisphosphate. Dotted arrow indicates expected effects. 
rheumatoid arthritis. Celastrus and its several constituents have shown to possess anti-oxidant, anti-inflammatory and anti-cancer properties [56]. Recently, Celastrus orbiculatus extract (COE) was shown to inhibit cell proliferation, adhesion and migration of human gastric cancer [57, 58], and induced apoptosis and autophagy in colorectal cancer cells by modulating the PI3K/Akt/mTOR signaling pathway [56]. Hao et al. also demonstrated decreased cell viability, adhesion, migration and invasion of U87 and U251 GBM cells by COE [59]. While this study didn't directly analyze the effect of COE on the $\mathrm{PI} 3 \mathrm{~K} / \mathrm{Akt} / \mathrm{mTOR}$ signaling pathway, the involvement of this pathway in regulating invasion and motility in both GBM cell models suggest that COE may be inhibiting the PI3K pathway. Further mechanistic studies are needed.

\section{Andrographolide}

Andrographis paniculata (AP) is a medicinal herb generally known as Kalamegha or Kalmega and widely distributed in India. Andrographolide, a bicyclic diterpenoid lactone isolated from the leaves of AP has been shown to possess anti-cancer activity against many tumors and was also shown to cross the BBB [60, 61]. Li et al., demonstrated that andrographolide inhibits U87 and $\mathrm{U} 251 \mathrm{GBM}$ cell proliferation by inducing $\mathrm{G}_{2} / \mathrm{M}$ cell cycle arrest, accompanied by decreased expression of proteins Cdk1 and Cdc25C [61]. They also showed inhibition of the PI3K/AKT/mTOR signaling pathway in U87 and U251 cells by andrographolide [61].

\section{Plumbagin}

Plumbagin is a bicyclic naphthoquinone that is present in the roots of Droseraceae, Plumbaginaceae and Ebenceae family members. It belongs to one of the widespread and diverse groups of plant metabolites. This natural pigment has antidiabetic, antioxidant, antimutagenic, anti-inflammatory and anti-proliferative properties against leukemia, melanoma, lung, breast, and prostate cancer [62-67]. The inhibitory effect of plumbagin was shown by modulating several signaling pathways including Akt/mTOR, NF-kB, and JNK. Recently, its effect was investigated on GBM cells and it was observed that plumbagin induced cell cycle arrest and DNA damage followed by apoptosis [68]. The mechanistic studies revealed upregulation of TNFRSF1A, PTEN and downregulation of E2F1 genes, MDM2, cyclin $\mathrm{B} 1$, survivin and $\mathrm{Bcl} 2$ protein expression along with increased caspase-3/7 activity. Strikingly, they observed that plumbagin inhibits telomerase activity and shortening of telomeres upon chronic plumbagin exposure [68]. Furthermore, they observed enhanced cytotoxicity of plumbagin to KNS60 GBM cells with higher telomerase activity than in U251 and A172 GBM cells with less activity [68].

\section{NATURAL PRODUCTS AS GBM RADIOSENSITIZERS}

RT alone or in combination with TMZ is the standard of care for most GBM patients. However, toxicity to normal tissues and development of resistance limits the efficacy of RT [69]. Therefore, agents that can radiosensitize tumor cells would not only prevent the development of resistant tumors, but may also help to reduce RT associated toxicity. Many synthetic and naturally derived compounds have been used as radiosensitizers for GBM. However due to the intrinsic immune enhancing properties of many natural products, they enhance RT effects with less toxicity to normal tissues. Natural compounds used or potentially to be used as radiosensitizers in GBM are discussed below.

\section{Guduchi}

Tinospora cordifolia, commonly called Guduchi, belongs to the family Menispermaceae. It has been used in ayurvedic treatment for centuries to treat jaundice and to protect liver function [70-72]. Its anti-angiogenic, anticancer, anti-inflammatory and radiosensitizing properties are also well documented [73-78]. Rao et al., demonstrated Guduchi's radiosensitizing activity in ehrlich ascites carcinoma (EAC) mice [79]. Interestingly, animals pre-treated with $30 \mathrm{mg} / \mathrm{kg}$ guduchi extract 1 hour before 6 Gy of $\gamma$-radiation and subsequent guduchi treatment for 6 days reduced the tumor growth and increased the overall survival of EAC mice compared to animals without pre-treatment [79]. Ethanolic extract of Guduchi EEG also inhibited the growth of C6 rat glioma cells and U87 GBM cells in a concentration dependent manner and also induced differentiation of C6 cells to an astrocyte-like phenotype [80]. In addition, EEG inhibited the migration and invasion of C6 cells associated with decreased matrix metalloproteinases -2 and -9 (MMP2 and MMP-9), NCAM and PSA-NCAM expression [80]. Furthermore, EEG-induced cell cycle arrest and senescence was accompanied by decreased expression of cyclin D1, Bcl-xL and increased expression of mortalin, a marker for senescence [80].

\section{Zataria multiflora}

Zataria multiflora is known as Avishan-e-Shirazi in Iran and belongs to the Lamiaceae family. In addition to containing a small percentage of saponins, caffeic acid, resin, tannin, and resonates, zataria extract (ZE) contains 69\% phenols-primarily carvacrol' P-cymene and thymol [81]. Many recent studies showed that ZE possesses anti-bacterial, anti-oxidative and anti-inflammatory activity and most importantly protected lymphocytes from radiotherapy [82-85]. More specifically, hydroalcoholic extract $(200 \mathrm{ug} / \mathrm{ml})$ of this plant significantly increased the radiosensitivity of A172 GBM cells in a 
concentration dependent manner and induced apoptosis [86]. Interestingly, ZE showed no antiproliferative or radiosensitizing effects in nonmalignant HFFF2 cells [86] suggesting its nontoxicity to the normal cells.

\section{Tetrandrine}

Tetrandrine (Tet) is a bisbenzylisoquinoline alkaloid that is isolated from the roots of Stephania tetrandra S. Moore, with known apoptotic, anti-angiogenic and radiosensitizing properties in many cancers [87, 88]. Recently, Tet was also shown to radiosensitize GBM cells U87 and U251 by significantly inhibiting their proliferation via inducing $\mathrm{G}_{0} / \mathrm{G}_{1}$ cell cycle arrest, attenuating the radiation induced ERK signaling pathway and decreased expression of proliferation associated genes PCNA and cyclin D1 [88].

\section{NATURAL PRODUCTS EFFECTING GBM CELL PROLIFERATION AND APOPTOSIS}

GBM is characterized by uncontrolled proliferation, local necrosis, diffuse infiltration, and increased angiogenesis [89]. In addition, like many other cancers, GBM cells are relatively resistant to apoptosis due to deregulation of pro- and anti-apoptotic proteins [90, 91]. Natural products that inhibit proliferation and induce apoptosis in GBM cells are summarized below.

\section{Alkaloids and flavonoids}

Zingiber officinale and Rhazya stricta belong to the Apocynaceae and Zingiberaceae families respectively. Alkaloids extracted from Rhazya stricta have antimicrobial and anticancer properties and chemosensitize many tumors [92-94]. While the flavonoids are known to exhibit antiangiogenic, pro-apoptotic and anti-cancer activities in in vitro and in vivo models [95, 96], effects of flavonoids of Zingiber officinale on GBM cells have not been explored extensively. Recently, Ayman et al., studied the effect of crude flavonoid and alkaloid extract of Zingiber officinale and Rhazya stricta, respectively, on a U251 GBM cell line. They observed that this combination resulted in synergistic growth inhibition, decreased clonogenic survival and induction of apoptosis [97]. They showed the induction of apoptosis was mediated by cytochrome c release from mitochondria, increased $\mathrm{Bax} / \mathrm{Bcl}-2$ ratio, caspase 3/9 activation and cleavage of poly (ADP-ribose) polymerase (PARP). Additionally, the crude extract induced apoptosis and was associated with decreased nuclear NF- $\kappa \mathrm{B}$, expression of survivin, XIAP, cyclin D1 and increased p53, p21, and Noxa expression [97].

\section{Oridonin}

Oridonin is diterpenoid compound extracted from the Chinese herbal medicinal plant Rabdosia rubescens. Oridonin was found to have anti-cancer activities against multiple cancers including breast, lung, leukemia and osteosarcoma [98, 99]. Recently, oridonin mediated inhibition of RanGTPase activating protein 1 (RanGAP1) was shown to induce apoptosis in U87 GBM cells by effecting nuclear cytoplasmic export of noncoding RNA (ncRNA) [100]. It is important to mention that tumor cells synthesize relatively very high ncRNAs and RanGAP1 is believed to be an important protein involved in nucleocytoplasmic export of ncRNA via the nuclear pore complex (NPC).

\section{Osthole}

Osthole or osthol is a natural coumarian, extracted from ripe cnidium fruits and known to have anti-oxidant, antiinflammatory and anti-cancer properties [101-103]. Recently, Kai et al. have shown that osthole treatment significantly reduced growth, enhanced apoptosis and increased the expression of the tumor suppressor microRNA-16 (miRNA-16) with decreased MMP-9 expression in U87 GBM cells [104]. Of note, immunohistochemical analysis in GBM revealed that MMP-9 expression is increased in GBM when compared to normal brain [105]. siRNA mediated silencing of MMP-9 resulted in decreased GBM proliferation and increased apoptosis [106, 107]. These studies suggest that osthole induced apoptosis may be mediated through MMP downregulation, which further needs to be explored.

\section{Cucurbitacin}

Cucurbitacins are terpene sterols that are extracted from the Cucurbitaceae family of plants and structurally classified into 12 groups [108]. Among them, cucurbitacins I, E, B, D and Q are well accepted for their anti-neoplastic activity in several cell lines [109-112]. The anticancer effects of cucurbitacins involve induction of cell cycle arrest and apoptosis by inhibiting the Janus kinase/Signal Transducer Activator of Transcription 3 (JAK/STAT3) signaling pathways. Dong et al. also reported that cucurbitacin $\mathrm{B}$ repressed proliferation and colony formation of U87 and T98G GBM cells. Further, cucurbitacin $\mathrm{B}$ disrupted actin and the microtubule network, resulting in loss of pseudopodia thereby inhibiting cell migration/invasion [113].

\section{Chokeberry extract and curcumin}

Chokeberry (Aronia melanocarpa) belongs to the Rosaceae family and is distributed in eastern North America. Polyphenolic extract of chokeberry (CPE) 
contains several flavonoids and anthrocyanins thought to penetrate the $\mathrm{BBB}$ [114]. Azela et al. reported recently that both $\mathrm{CPE}$ and curcumin decrease the viability of U373 GBM cells [115]. While CPE decreased viability by inducing necrosis, curcumin directly induced apoptosis in U373 GBM cells [115]. Furthermore, both of these compounds downregulated MMP-2, MMP-14, MMP16 and MMP-17 mRNA levels [115]. Since MMPs are an integral part of the $\mathrm{BBB}$ and maintain its integrity, curcumin and CPE mediated decrease of MMP's may modulate $\mathrm{BBB}$ permeability and may enhance drug diffusion.

\section{Jaceosidin}

Artemisia argyi (AA), generally known as silvery wormwood, belongs to the Compositae family and is distributed throughout the world. Muhammad et al. isolated Jaceosidin from the leaves of AA and analyzed its anti-cancer activity on U87 GBM cells [116]. He observed that Jaceosidin treatment inhibited proliferation, induced cell cycle arrest in the $\mathrm{G}_{2} / \mathrm{M}$ phase and promoted apoptosis. This increased apoptosis was accompanied by an increase in the proapoptotic protein Bax and p53 expression, and abolished the mitochondrial membrane potential (MMP), cytochrome $\mathrm{C}$ release to cytoplasm and activation of caspase-3 [116].

\section{Trichosanthin}

Trichosanthin (TCS) belongs to the family of plant proteins known as ribosome-inactivating proteins (RIPs) and is isolated from the roots of the herb Trichosanthes kirilowii, generally known as Chinese snake gourd and Chinese cucumber. TCS is traditionally used in Chinese medicine for inducing midterm abortion [117]. By virtue of its rRNA N-glycosidase activity, it attacks the eukaryotic cell ribosomes and inhibits protein translation [117]. TCS exhibits antitumor effects against cervical cancer, choriocarcinoma, leukemia and lymphoma. In addition, TCS has also been shown to significantly inhibit proliferation of U87 and U251 cells [118] and increase apoptosis in U87 cells by decreasing the leucine-rich repeat containing G-protein coupled receptor 5 (LGR5) and $\mathrm{Wnt} / \beta$-catenin expression [118]. Importantly, LGR5 expression positively correlates with increasing histologic grade of astrocytoma - from grade II to GBM (grade IV) - and is associated with poor survival [119]. LGR5 mRNA levels are also higher (10 fold) in the GBM CSCs than healthy brain astrocytes. Predictably, adenovirus mediated silencing of LGR5 induced cell death in GBM CSCs [119].

\section{$\gamma$-Mangostin}

$\gamma$-Mangostin is a xanthone derived from Garcinia mangostana, commonly known as mangosteen "the queen of fruit". Hui-Fang et al. reported significant inhibition of growth and apoptosis of U87 and 8401 GBM cells in a concentration dependent manner by $\gamma$-Mangostin [120]. Further, the biochemical investigation revealed that $\gamma$-Mangostin induced apoptosis was associated with increased hypodiploid cells, mitochondrial dysfunction and increased ROS production [120]. In addition to GBM, $\gamma$-Mangostin also showed anti-proliferative effects on human colon cancer DLD-1 cells [121].

\section{Thymoquinone}

Thymoquinone (TQ), is the major bioactive compound extracted from Nigella sativa seed, commonly known as black seed and is vastly distributed in India, Eastern and European countries. TQ is known for its anticancer activities against several cancer cell lines with low toxicity to normal cells [122-124]. Recent study has shown inhibition of proliferation of Gli36EGFRvIII, T98G and U87 GBM cells by TQ [125]. They also observed that this decrease in cell proliferation was independent of p53 status and may occur through inhibition of autophagic flux [125]. In addition to GBM, our lab has also shown strong antitumor effects of thymoquinone against pancreatic cancer [126].

\section{Brazilin}

Brazilin is a red pigment extracted from the central wood of the Caesalpinia sappan with known anti-oxidant, anti-inflammatory and anti-proliferative properties [127]. In addition, Dae-Young also demonstrated that brazilin also decreased proliferation and induced apoptosis in U87 GBM cells as shown by the cell cycle arrest at sub- $\mathrm{G}_{1}$ phase, while decreasing the expression of caspase -3 and caspase-7, and increasing the expression of PARP [127].

\section{Betulinic acid}

Betulinic acid (BetA), is a pentacyclic triterpenoid extracted from birch trees (Betula pubescens) and selfheal (Prunella vulgaris). Besides anti-retroviral, anti-malarial, and anti-inflammatory properties, recent studies have shown it to exhibit potent anti-cancer activity against several human cancers with no significant effect on normal cells [128-130]. Interestingly, it was shown to induce apoptosis in human neuroblastoma cells in vitro and in vivo [131]. In addition, by activating a p53 independent caspase - PARP cascade, BetA induced apoptosis in five glioma cell lines [132]. BetA induced cell death was associated with increased levels of the proapoptotic protein $\mathrm{BAX}$, formation of ROS, and DNA fragmentation 
[132]. Similarl observation of BetA induced cell death was also reported by Simone. et al using a large panel of malignant brain tumor cells [133].

\section{Deoxypodophyllotoxin}

Deoxypodophyllotoxin (DPT) is a semi-synthetic compound isolated from Dysosma versipellis extract. Mounia et al. identified that DPT treatment significantly inhibited the proliferation coupled with $\mathrm{G}_{2} / \mathrm{M}$ cell cycle arrest in U87 and SF126 GBM cells at nanomolar concentrations [134]. It decreased the expression of cell cycle regulatory proteins including cyclin $\mathrm{B} 1, \mathrm{Cdc} 2$ and Cdc25C in U87 GBM cells [134]. In addition, DPT treatment also induced apoptosis in both U87 and SF126 cells by abolishing the MMP, while decreasing the expression of Bcl-xL and Bcl-2 [134].

\section{Nardostachys jatamansi}

Nardostachys jatamansi (NJ) commonly known as spikenard, nardin, nard or muskroot belongs to the Caprifoliaceae family and is found at high altitudes in India. Crude extracts from the $\mathrm{NJ}$ are effective against parkinsonism and epilepsy in experimental brain models [135, 136]. A methanol extract (ME) of NJ rhizome significantly inhibited the proliferation of U87 GBM cells with less cytotoxicity to human embryonic kidney (HEK) cells, suggesting its relative safety to normal cells. ME also induced DNA fragmentation coupled with apoptosis in U87 cells [137].

\section{Variolin B and Meridianins}

Uncontrolled proliferation due to sustained activation of cyclin-dependent kinases (CDKs) is the hallmark of most cancers, leading to the widespread investigation of inhibitors specific to CDKs. The cyclin D-CDK4/CDK6 signaling pathway is deregulated in GBM and results in uncontrolled cell cycle progression $[138,139]$ making it a viable targeted therapeutic option. Natural compounds like Variolin B and Meridianins isolated from the marine Ascidian Aplidium meridianum inhibit CDK activity [140]. Recently, synthetic hybrid molecules called meriolins were derived from meridianins, and shown to induce apoptosis in neuroblatoma SHSY5Y cells [141]. Comparative analysis of a panel of meriolins showed that meriolin- 15 significantly inhibited proliferation and induced apoptosis in GBM cells [142].

\section{Xanthones and Lactones}

Xanthones belong to class of tricyclic compound with known anti-cancer, anti-microbial and antiinflammatory activities [143-145]. The Cudraxanthone-I xanthone extracted from Milicia excelsa significantly inhibited the proliferation of the U87 and resistant U87 EGFRvIII GBM cell lines [146]. Lactones derived from the Vernonia cinerea (little ironweed or ash fleabane) of the Asteraceae family have antimalarial, antiinflammatory and anti-metastatic properties [147-149]. Sesquiterpene lactones isolated from Vernonia cinerea significantly inhibited STAT3 activity in U251 GBM cells and decreased their viability [150].

\section{Salidroside}

Salidroside or rhodioloside, a glucoside of tyrosol, is obtained from root extracts of Rhodiola crenulata. Salidroside exhibits anti-cancer activities against gliomas, gastric, breast and lung cancers [151]. Similarly, purified salidroside also inhibited proliferation and induced $\mathrm{G}_{0} / \mathrm{G}_{1}$ cell cycle arrest of glioma U251 cells [152]. Crude extract from the root (CER) also decreased proliferation and clonogenic survival of U87 GBM cells [153]. Of note, CER mediated decrease in cell proliferation was associated with inhibition of Wnt/ $\beta$-catenin signaling and enhanced glial fibrillary acidic protein (GFAP) expression [153].

\section{Rutin}

Vascular endothelial growth factor (VEGF) and transforming growth factor- $\beta 1$ (TGF- $\beta 1$ ) are the two major cytokines recognized to influence GBM cell migration, invasion and angiogenesis [154, 155]. Rutin, a flavonoid isolated from seeds of Dimorphandra mollis , is commonly known as faveira. Interestingly, rutin was shown to inhibit the production of both VEGF and TGF- $\beta 1$ in GBM GL-15 cells and therefore, inhibit angiogenesis and CRT resistance [155]. It is interesting to note that the anti-VEGF antibody bevacizumab suppresses VEGF production but doesn't affect TGF- $\beta 1$ expression or activation [155]. Rutin is known to inhibit skin cancers as well [156].

\section{Lichen derivative}

Lichens are complex organisms, made of fungal filaments and one or more cyanobacteria or photosynthetic algae. Protolichesterinic acid, lobaric acid, usnic acid and vulpinic acid isolated from lichens were found to have anti-proliferative, anti-oxidant, and antibiotic activities $[157,158]$. The methanolic extracts (ME) of lichens Cladonia rangiformis and Cladonia convolute significantly inhibited proliferation of the GBM cell line U251 [159]. Recently, it was also reported that olivetoric and psoromic acid from lichens significantly reduce the viability of U87 GBM cells possibly by inducing oxidative DNA damage [160].

\section{Cactus}

Opuntia humifusa, generally known as the devil's tongue, belongs to the Cactaceae family $[161,162]$ and its extracts display antibacterial and anti-oxidant effects [163]. While the ethyl acetate extract (EAE) of cactus 
show cytotoxicity against colon, cervical and breast cancer cells, hexane extract (HE) and water partitioned fraction (WPF) decreased proliferation of U87 GBM cells [163]. This WPF induced decrease in cell proliferation was associated with $\mathrm{G}_{1}$ phase cell cycle arrest, enhanced ROS generation and non-apoptotic cell death [163].

\section{Diosquinone}

Diosquinone, a napthoquinone epoxide, is extracted from the root bark of Diospyros mespiliformis (Hostch) and Ebenaceae Diospyros tricolor. Recent study has shown that Diosquinone inhibited cell proliferation of many cancer cells including GBM [164]. They further reported greater cytotoxicity of Diosquinone against p53 mutant GBM cell line U373 than lung, colon, prostate and neuroblastoma cancer cell lines [164].

\section{Tithonia diversifolia}

Survivin is a member of anti-apoptotic gene family whose expression is elevated in most solid tumors with undetectable to minimal expression in normal and differentiated cells [165]. Overexpression of survivin is associated with tumor recurrence and drug resistance [166168]. The medicinal herb Tithonia diversifolia, generally known as Mexican sunflower or Japanese sunflower, has known anticancer activities against human colon cancer Col 2 cells and human promyeleocytic leukemia HL-60 cells [169]. In addition, crude Tithonia diversifolia extract and its principal compound tagitinin $\mathrm{C}$ also inhibited growth of U373 GBM cells by downregulating survivin expression in a dose dependent manner [170].

\section{Zeng sheng ping}

Zeng Sheng Ping (ZSP) is a Chinese herbal mixture containing Polygonum bistorta, Sonchus brachyotus, Dioscorea bulbifera, Sophora tonkinensis, Prunella vulgaris and Dictamnus dasycarpus. Kah et al., reported that ZSP inhibited proliferation and survival of U87 cells possibly by downregulating Notch2 and its signaling component Hes1 [171]. ZSP also decreased expression of the stem cell markers CD133 and nestin in U87 cells [171]. Notch signaling is highly activated in GBM and targeting this pathway prevented tumor growth and improved survival [172-175]. In addition, many pre-clinical studies showed antitumor effects of ZSP against colon and esophageal cancers [176-178]. More importantly, many clinical studies also showed that ZSP significantly prevented the progression (48-52\%) of esophageal cancers [179-181].

\section{Tanacin}

Tanacetum huronense is commonly known as Lake Huron tansy. Ethyl acetate extract of this plant and its bioactivity based purification have yielded six sequiterpenoid lactone compounds. Among them, compound 4 (tanacin) displayed highest inhibitory effect against the U87 GBM cell line [182].

\section{Procyanidins}

Procyanidins, a class of flavonoids, are oligomeric compounds formed from catechin and epicatechin molecules. They are mostly present in grape seeds, grape skin, apples, cinnamon, cocoa beans etc. These procyanidins can be grouped into 7 fractions (F1 to F7) depending upon their degree of polymerization. Recent studies have shown that $\mathrm{F} 2$, after crossing the BBB, protected mouse brains from ethanol induced oxidative damage $[183,184]$. Zhang et al., showed that F2 treatment inhibited proliferation of U87 cells by inducing $\mathrm{G}_{2} / \mathrm{M}$ cell cycle arrest and reducing MMP expression while causing little toxicity to normal cells [185]. More recently, Hong et al. also showed that F2 inhibits U251 GBM cell invasion and angiogenesis by downregulating hypoxia inducible factor 1 alpha (HIF-1 $\alpha$ ) mediated MMP-2 and VEGF expression [184]. In addition, F2 also inhibited formyl peptide receptor, a type of G-protein coupled receptor that is known to be intricate in GBM tumor invasion and angiogenesis [185].

\section{Quercus petraea}

Quercus petraea, commonly known as the sessile oak, is predominantly found at Walloon forest region in Belgium. Michel et al., discovered that ME of Quercus petraea stem bark efficiently inhibit the growth of GBM cell line U373 [186].

\section{Ochnaflavone}

Ochna kibbiensis and Ochna schweinfurthiana belong to the Ochnaceae family and is distributed in Northern Nigeria. The ethyl acetate extract (EAE) and ME from the leaves of this plant showed cytotoxicity to human GBM cells U-1242, though EAE was more potent than ME [187]. While these results implicate the presence of anti-GBM molecules in Ochna kibbiensis [187], its antiproliferative effects still needs to be investigated.

\section{Salvia menthaefolia and Ficus bubu}

Salvia menthaefolia is a Chinese herbal medicinal plant from the Lamiaceae family. Giovina et al., found that ME of Salvia menthaefolia roots significantly inhibited the viability of the U87, T98G and DBTRG-05MG human GBM cell lines [188]. Similarly, the ME from leaves of another plant Ficus bubu (Moraceae family) also inhibited the proliferation of U373 GBM cells [189].

\section{Auron-misheil-therapy}

Auron-Misheil-Therapy (AMT) is a complex mixture comprising of camolile extract (isolated from 
chamomile blossom) and additives including human insulin, vitamins, calcium and the antihistamine chlorpheniramine. AMT promotes body weight gain and has been used as palliative for pain in the patients with end stage cancers for decades. In addition, recently AMT was shown to inhibit proliferation of U87, LN-229, CNXF 498NL, SF-268 and SF-295 GBM cells along with decreased anchorage independent growth of CNXF 498 and SF-268 GBM cells [190].

\section{EFFECTS OF NATURAL PRODUCTS ON GBM PRE-CLINICAL MODELS}

The anatomical, physiological and genetic makeup of mice relatively recapitulates that of humans [191] and hence they are powerful models to test therapeutic efficacy, investigate pharmacokinetics and characterize acute and chronic toxicities of newly discovered drugs. Here we have summarized all the natural products with anti-tumorigenic effects on GBM mouse xenograft models Table 2 .

\section{Withaferin}

Withania somnifera, traditionally known as Ashwagandha, has been used in ayurvedic medicine for several thousand years [192]. It contains numerous compounds including 40 withanolides, 12 alkaloids, multiple flavonoids and sitoindosides extracted from different parts of the plant [193, 194]. Among them, Withaferin A appeared to be the most bioactive compound with anti-invasive, anti-angiogenic, antiinflammatory and pro-apoptotic effects [195]. Grace et al. studied the anti-oxidative and anti-inflammatory effects of two withanolide components, namely, Withanolide A and Withaferin A in microglial cells [196]. Surprisingly, withanolide components not only abolished lipopolysaccharide (LPS) stimulated nitric oxide production and ROS generation, they also induced nuclear factor (erythroid-derived 2) like 2 (Nrf2) signaling followed by upregulation of hemeoxygenase-1 (HO-1) [196]. Though both withanolide components displayed anti-oxidative and anti-inflammatory effects, Withaferin A was found to be 10 fold more effective than Withanolide A [196]. In addition, EE of Withania somnifera leaves significantly inhibited the proliferation of C6 rat glioma and YKG1 human glioma cell lines in a dose dependent manner [197]. Recently, Patrick et al., demonstrated that Withaferin A treatment significantly decreased the proliferation of U87, U251 and TMZ resistant GBM cell lines U87 TMZ, U251 TMZ, T98G and U138 as well in a concentration dependent manner [53]. Moreover, it increased TMZ sensitivity by downregulating MGMT expression in U251 TMZ, T98G and U138 TMZ resistant GBM cell lines [53]. Interestingly, oral administration of Withania somnifera water extract (4 $\mathrm{ml} / \mathrm{kg} /$ day) significantly reduced the tumor volume in a rat orthotopic glioma allograft model [198]. In addition, an intraperitoneal administration of Withaferin A (12 mg/kg) for 3 days in a week for three weeks also resulted in $40 \%$ improvement in median survival of orthotropic xenograft mouse model [199].

\section{Curcumin}

Curcumin, a constituent in turmeric, is derived from the herb Curcuma longa that belongs to Zingiberaceae family and used as an ingredient in cooking in some part of India. Curcumin displays significant growth inhibition, prevents angiogenesis and induces apoptosis in in vitro and in vivo models of many cancers [200]. In GBM, curcumin has been shown to attenuate the intracranial tumor growth of U87 xenografts and increased the overall survival of the mice [201]. Although it's low bioavailability in humans owing to poor absorption and fast clearance from the body has limited its anti-cancer effects [202, 203], recent research has shown that turmeric rhizomes that are subjected to supercritical (CO2) and hydroethanolic isolation yields an extract known as Turmeric Force ${ }^{\mathrm{TM}}$ (TF). The TF contains $11 \%$ curcuminoids, $45 \%$ turmerones and some other molecules that display more cytotoxicity against cancer cell lines than turmeric [204]. Cheppail et al., also showed that addition of TF to either etoposide or TMZ increased the cytotoxicity in U87 GBM cell line. They further showed that the triple drug combination of TF with etoposide plus TMZ was even more cytotoxic to the U87 cell line [205]. Compellingly, tumerones from TF were also shown to cross the BBB [206]. The extract from the other curcuma species, Curcuma amada (CA) also significantly reduced the viability of human embryonal (RD) and alveolar (SJRH30) rhabdomyosarcoma cells [207]. The underlying antitumor mechanism showed that CA treatment attenuates AKT signaling, and downregulates anti-apoptotic genes in U87 cells [208]. It is important to mention that AKT is a serine/threonine protein kinase B involved in regulating several biological functions including cell proliferation and invasion, apoptosis inhibition, angiogenesis [209], and chemotherapeutic resistance [210-213]. Activated AKT is known to inhibit apoptosis by abolishing the cytochrome-c release from the mitochondria and inactivating pro-apoptotic proteins procaspase-9 and BAD by phosphorylation [214, 215]. Further, no significant effect on the control mouse hypothalamus cell line (mHypoE-N1) suggests that CA may be nontoxic to normal brain cells.

\section{Angelica sinensis}

Angelica sinensis, commonly known as dong quai or "female ginseng", is an herb from the family Apiaceae. It 
Table 2: Natural products which displayed anti-cancer activities in GBM pre-clinical models

\begin{tabular}{|c|c|c|c|c|}
\hline S. No & Scientific Name & Component & Function & Refs \\
\hline 1 & Withania somnifera & Water extract & $\begin{array}{l}\downarrow \text { tumor volume in rat orthotopic glioma allograft } \\
\text { model }\end{array}$ & [198] \\
\hline 2 & Withania somnifera & Withaferin A & $\begin{array}{l}\uparrow \text { median survival of orthotopic xenograft mouse } \\
\text { model by } 40 \%\end{array}$ & [199] \\
\hline 3 & Curcuma longa & Curcumin & $\begin{array}{l}\downarrow \text { intracranial tumor growth of U87 GBM xenografts } \\
\text { and } \uparrow \text { the overall survival of mice }\end{array}$ & [201] \\
\hline 4 & Angelica sinensis & $\begin{array}{l}\text { Root chloroform } \\
\text { extract }\end{array}$ & $\begin{array}{l}\uparrow \text { apoptosis in both p53 independent and dependent } \\
\text { pathways } \\
\downarrow \text { tumor growth in a rat GBM model \& human GBM } \\
\text { orthotopic model }\end{array}$ & {$[220]$} \\
\hline 5 & Ardisia pusilla & $\begin{array}{l}\text { Ardipusilloside } 1 \\
\text { (ADS-1) polymer } \\
\text { microspheres }\end{array}$ & $\begin{array}{l}\text { able to retain ADS- } 1 \text { release for } 36 \text { days in in vitro } \\
\text { Higuchi model of kinetics; inhibited tumor growth } \\
\text { in vivo C6 intracranial tumor model and } \uparrow \text { overall } \\
\text { survival of the animal }\end{array}$ & [224] \\
\hline 6 & Berberis aristata & Berberine & $\begin{array}{l}\text { elicited more cytotoxicity than TMZ in U87, U251 } \\
\text { and U118 GBM cell lines; } \\
\downarrow \text { EGFR-RAF-MEK-ERK signaling and induced } \\
\text { senescence; } \downarrow \text { tumor growth in GBM xenografts }\end{array}$ & {$[237]$} \\
\hline 7 & Anemone taipaiensis & Saponin 1 & $\begin{array}{l}\downarrow \text { expression of survivin, XIAP, Bcl-2/Bax ratio, } \\
\text { activating caspase-9, caspase-3 and apoptosis in } \\
\text { U251 and U87 GBM cell lines; } \downarrow \text { tumor growth in } \\
\text { U251 and U87 GBM xenografts in mice }\end{array}$ & [238] \\
\hline 8 & Panax ginseng & Ginsenoside RG3 & $\begin{array}{l}\uparrow \mathrm{TMZ} \text { sensitivity, } \downarrow \text { VEGF-A and } \mathrm{BCl}-2 \text { in HUVEC } \\
\text { and rat glioma cell lines; } \\
\text { RG3 and TMZ combinational treatment significantly } \\
\downarrow \text { angiogenesis. }\end{array}$ & {$[244]$} \\
\hline 9 & Iris versicolor & Iridin & $\begin{array}{l}\downarrow \text { intracranial growth of U87 and G144 GBM } \\
\text { xenografts in mice }\end{array}$ & {$[257]$} \\
\hline
\end{tabular}

is acknowledged for its efficacy in treating gastric mucosal damage, chronic glomerulonephritis and diminished myocardial blood flow [216-219]. Angelica sinensis root chloroform extract treated GBM cell lines undergo apoptosis in both p53 independent and p53 dependent pathways [220]. It curbed tumor growth in a rat GBM model, and in a GBM orthotopic model, suggesting that it might pass through the BBB [220].

\section{Ardipusilloside 1}

Ardipusilloside 1 (ADS-1) is a triterpenoid saponin, extracted from the medicinal herb Ardisia pusilla with well known anti-cancer activity on GBM cell lines [221, 222]. Unfortunately, a short half-life in plasma (5.61 h) of ADS-1 due to deglycosylation [223] limits its therapeutic efficacy in vivo. However, recently developed ADS-1 polymer microspheres packed into wafers [224] have increased its half- life to 36 days in in vitro and in vivo. In animal models, these polymers significantly reduced the $\mathrm{C} 6$ intracranial tumors and increased overall survival [224]. Mechanistically, the decrease in tumor growth was due to decreased tumor necrosis factor $-\alpha$, interleukin-6, C-reactive protein, VEGF and upregulation of interleukin-2 expression [224].

\section{Toosendanin}

Toosendanin (TSN) is a triterpenoid saponin isolated from the Chinese herb Melia toosendan and is known to inhibit acetylcholine release at the nerve terminals. Though used as a pesticide, recent studies have shown its anti-proliferative effect against lymphoma, leukemia and hepatocellular cancer cell lines [225-228]. In addition, TSN also inhibits proliferation of U87 and C6 cell line at nanomolar (10 nM) concentrations [229]. Additionally, TSN reduced the growth of U87 xenografts in vivo feasibly by upregulation of p53 and estrogen receptor $\beta$, which are known tumor suppressors in many cancers [229-231].

\section{Berberine}

The alkaloid berberine is extracted from the stem bark, rhizome and root of several Chinese medicinal 
plants including Berberis aristata, Berberis aquifolium and Tinospora cordifolia [232, 233]. Berberine shows significant antihelmintic, anti-inflammatory, antimicrobial and antioxidative properties $[234,235]$. Ki et al. demonstrated apoptosis inducing effects of berberine on human GBM T98G cells in a concentration dependent manner [236]. Furthermore, berberine induced cell death was coupled with increased ROS production, intracellular calcium levels and endoplasmic reticulum (ER) stress [236]. A recent study showed more cytotoxicity of berberine in U87, U251, and U118 GBM cells than by TMZ [237]. They showed that berberine induced senescence was associated with EGFR-RAF-MEK-ERK signaling pathway inhibition. They further reported growth inhibition of GBM xenografts using berberine [237].

\section{Saponins}

Anemone taipaiensis from the Ranunculaceae family is a traditional Chinese medicine used against rheumatism and phlebitis. Recent studies demonstrated that saponin-1 and saponin-B from the Anemone taipaiensis inhibited the growth of brain tumor in vitro and in vivo [238, 239]. Mechanistic studies revealed that saponin-B induced apoptosis in U87MG cells was associated with cell cycle arrest in S phase, activation of Fas-1, increased Bax/Bcl-2 ratio and caspase-3 activation [239]. Similarly, saponin-1 was shown to decrease survival and induce apoptosis in U251MG and U87MG cells by decreasing the expression of survivin, XIAP, Bax/Bcl-2/ ratio and activation of caspase-9/3 [238]. Moreover, Li et al. also showed that saponin-1 inhibited the growth of U251MG and U87MG xenografts in nude mice [238]. Similarly, saponin-6 also induced cell cycle arrest and apoptosis in U87 MG cells by DNA fragmentation, increasing caspase 3/9 activity, increasing expression of Fas and Fas ligand, and decreasing Bcl2 expression [240]. In a comparative analysis, Xiaoyang showed that oleanane type saponins display more cytotoxicity to U87 GBM cells than to benign human lung (A549), hepatocellular (HepG2), cervical (Hela) and human promyeleocytic leukemia HL-60 cell lines [241].

\section{Ginsenoside RG3}

Ginsenoside RG3 is mainly extracted from Panax ginseng (or ginseng) that is widely used as a medicinal plant in Asia [242]. Ginsenosides are triterpenoid saponins and ginsenoside RG3 comes under protopanaxatriols group, in which sugar moieties are linked to the $\beta-\mathrm{OH}$ group at C-20 or C-3 [243]. Caixing et al. showed that ginsenosides RG3 increased TMZ sensitivity in C6 rat glioma cells, downregulated VEGF-A and $\mathrm{BCl}-2$ and induced apoptosis in HUVEC [244]. In addition, ginsenosides RG3 combined with TMZ also significantly reduced angiogenesis [244].

\section{Natural products on GBM Cancer Stem Cells}

CSCs also termed tumor initiating cells are a very small population of cancer cells that are responsible for the tumor initiation and resistance to CRT [245-247]. In GBM, CSCs are distributed in a specialized location known as the perivascular niche (PVN), which also harbors endothelial cells, astrocytes, tumor cells, microglia and pericytes [248, 249]. The PVN is presumed to maintain stemness and thereby the resistant nature of the CSCs [250-253]. While conventional CRT has been shown to enrich the CSC population and promote tumor recurrence, natural products may better target CSCs in multiple cancer types including GBM [254-256]. Rajarshi et al., identified three plant based non-toxic natural compounds from the Microsource Spectrum Collection library (MSCL)namely, Iridin, triacetyl-resveratrol (TAR) and tigogeninwhich specifically target the PVN [257] and inhibit the intracranial growth of U87 and G144 GBM xenografts in mice [257], suggesting that additionally targeting the PVN may improve survival of GBM patients.

CSCs that are isolated from GBM8401 cells are resistant to the cytotoxic drug TMZ [258]. MSC500 is a Korean natural medicine recipe consisting of eight herbs including Gastrodia elata, Phellinus linteus, and Mulberry leaves. Interestingly, MSC500 treatment to the GBM8401 cells resulted in a dose dependent decrease in aldehyde dehydrogenase (ALDH) activity associated with a reduction of the CSC population [258]. In addition, it downregulated the expression of $\mathrm{ABC}$ transporters (ABCG2 and ABCB5) in GBM8401 CSCs, known to impart drug resistance [258]. While a recent study showed decreased CSC population (from $3.6 \%$ on day 3 of treatment reduced to $0.55 \%$ on day 10 ) by curcumin in the C6 rat glioma cells [259]; its encapsulation using a biodegradable nanocarrier dentrosome (DC) also reduced the growth of U87 cells and decreased the expression of pluripotency genes like Nanog, SOX2, OCT 4A \& 4B1 [260, 261]. DC also increased the expression of tumor suppressor miRNA-145, which is usually downregulated in several tumor tissues $[260,261]$. It is noteworthy that polyurethane-short branch polyethylenimine vehicle mediated miRNA-145 delivery in CSCs abolished their stemness [262]. Other studies showed that by inhibiting PI3K/AKT/NF-kB signaling and decreasing MMP-2 expression, resveratrol inhibited GBM CSCs invasion in both in vitro and in vivo models [263]. Similarly, eckol, a phlorotannin compound extracted from Ecklonia cava with known anti-oxidant activity [264, 265] was shown to suppress the stemness in U87 and U373 GBM cells and in GBM patient derived CSCs XO1 GB and XO3 AOA by inhibiting PI3K/Akt and Ras/Raf-1/Erk signaling [266]. In another study, eckol was also shown to abolish the anchorage independent growth of U373 glioma cells and growth of xenografts [266]. It is not yet clear if the mechanism of action for this effect on CSCs was mediated through ROS generation. 


\section{Natural products and Blood Brain Barrier}

As GBM is highly invasive in nature, resection of all microscopic disease is not practically feasible, even when tumor is in non-eloquent regions. Though targeted therapy has attracted much attention, it has not increased the overall survival (OS) of GBM patients, due partly to the poor penetration of drugs through the BBB. Therefore, agents capable of modulating the BBB permeability to improve the bioavailability of therapeutic drugs to the tumors are highly desirable.

The BBB is a complex cellular vascular structure that by paracellular or transcellular pathways regulates the access of molecules to the brain. It is composed of numerous tight junctions between endothelial cells, ATP dependent multidrug resistance (MDR) pathway proteins known as P-glycoprotein (P-gp), enzymes, and receptors [267]. While the phosphorylation of endothelial tight junctional (TJ) proteins, occludin or zonula occludens-1 (ZO-1) regulate the paracellular permeability of the BBB [268], pharmacological inhibition of P-gp can increase drug influx to the brain [269]. The BBB microenvironment that includes astrocytes, microglia, pericytes, neurons, fibroblasts, basement membrane, extracellular matrix (ECM) and adjacent cell types [270], also influence BBB functions [271, 272]. The BBB of tumors (BBB) originates from tumor capillaries supplying nutrients and oxygen to the tumor [273]. The glioma BBTB microenvironment consists of tumor cells, ECM, tumor -associated microglia, infiltrating macrophages and other cell types. Interestingly, targeting the glioma microenvironment suppressed tumor growth in rat GBM models [274].

Natural products are known to modify the BBTB microenvironment through modulating the function of endocytosis, P-gp and secretion of MMPs. Shikonin, the prominent naphthoquinone isolated from a medicinal herb Lithospermum erythrorhizon, is known for its anti-oxidant and anti-inflammatory activities [275-277]. Lina et al., found that shikonin treatment significantly suppressed MMP-9 expression while it increased claudin-5 and BBB permeability in mice after ischemic stroke [278]. Additionally, shikonin treatment was found to reduce the viability, migration and invasion of the GBM cell lines U87 and U251 and also to decrease the expression of MMP-2 and MMP-9, conceivably through the inhibition of PI3K/Akt signaling [279]. Haidong et al., observed that
I

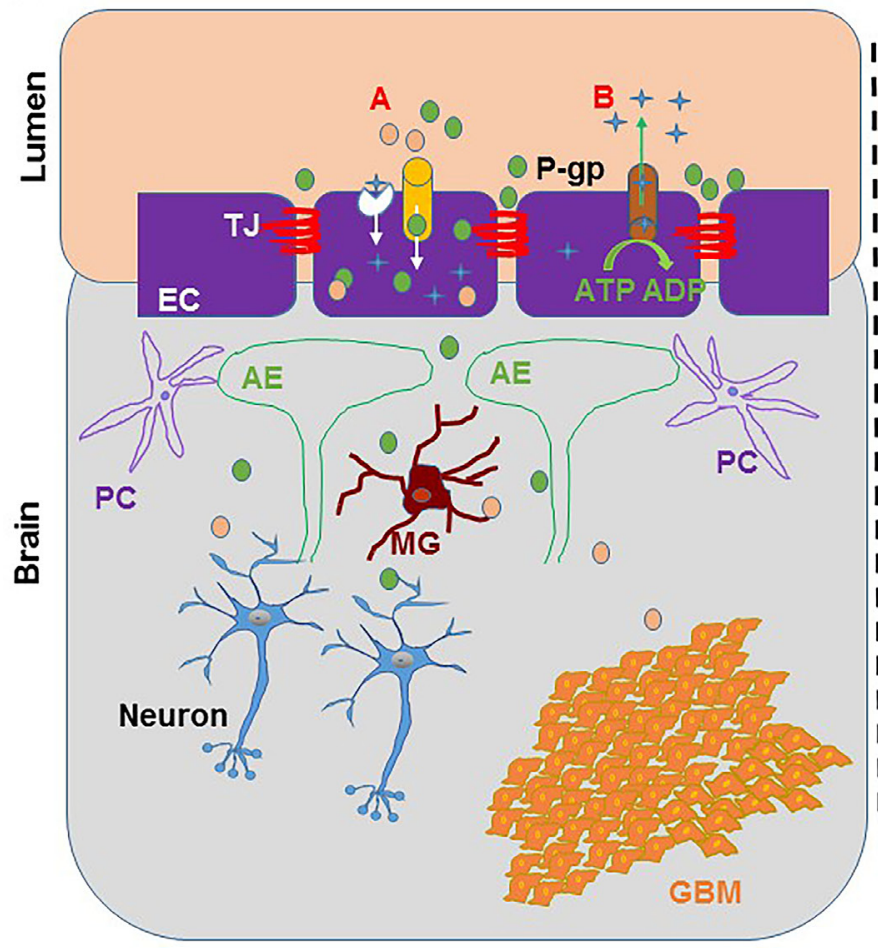

II

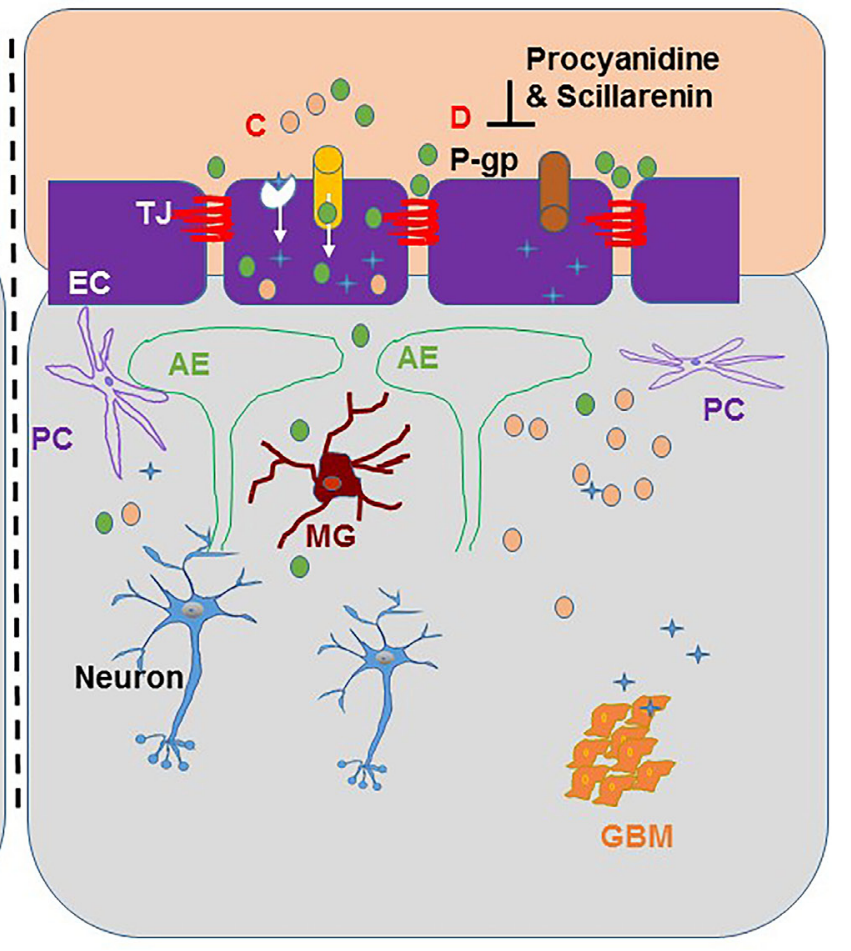

Figure 2: Natural products modulating blood brain barrier permeability. Natural products aid the permeation of chemotherapeutic drugs in the brain. On the left of the diagram I: A- shows the influx of sugars and amino acids from the blood to the brain by a selective nutrient transporter in the endothelial cells, identified as solute carrier proteins and passive diffusion of chemotherapeutic lipophilic drugs; B- showing P-gp present in the endothelial cells pumps out most drugs in a ATP dependent manner and lowers the drug concentrations in the brain. On the right side of diagram II: C \& D- shows natural compounds like procyanidine and scillarenin inhibit P-gp protein thereby allow accumulation of drug ( $\mathbf{+})$ in the brain to reduce the tumor burden. TJ, Tight junctions; EC, endothelial cells; P-gp, P-glycoprotein; PC, pericytes; AE, astrocytic endfoot; MG, microglia. 
resveratrol treatment protects the integrity of the BBB by regulating expression and activities of MMP-9 and TIMP1 in rat brains that were re-perfused after ischemic insult [280]. Similarly, procyanidine from the bark of Pinus massoniana also modulated microvessel endothelial cell permeability perhaps by modulating $\mathrm{P}$-gp proteins in a rat brain model. More interestingly, procyanidine increased adriamycin permeation through BBB resulting in enhanced therapeutic efficacy and increased overall survival of mice [281]. In addition, Scillarenin from scilla [272], has also been shown to prevent P-gp mediated efflux [282] (Figure 2). Yan-feng et al. also demonstrated that during hypoxia and glucose deprivation, curcumin maintains the BBB integrity by regulating ZO-1 and occludin expression [283].

\section{SUMMARY AND CONCLUSION}

GBM, the most common malignant brain tumor in adults, remains incurable with a bleak median survival. Despite multiple efforts there have been very few FDA approved drugs for its treatment, which are not universally efficacious. The efficacy of TMZ, a DNA alkylating agent used in first line therapy, is weakened by the expression of MGMT, which repairs the DNA damage induced by TMZ. Interestingly, multiple compounds from natural sources namely resveratrol, icariin, quercetin, propolisis, Turmeric Force ${ }^{\mathrm{TM}}$ and Withaferin A work synergistically with TMZ [28, 32, 33, 37, 49, 53, 205]. Zataria multiflora hydroalcoholic extract and Tet also significantly increased the radiosensitivity of the A172 and the U87 and U251 GBM cell lines respectively [86, 88]. Resveratrol, Withaferin A, quercetin, methanolic extract of Salvia menthaefolia roots, berberine, Ficus carica latex, propolisis, AMT, thymoquinone and cucurbitacins efficiently blocked cell proliferation and induced apoptosis, even in the TMZ resistant GBM cell lines [27, 32, 42, 49, 53, 113, 125, 188, 190, 236]. Moreover, TMZ induced cytotoxicity may be modulated by wild type p53 status. It has been observed that siRNA mediated silencing of p53 confers resistance to TMZ [284]. Toosendanin from Melia toosendan increased the p53 expression [229] and betulinic acid from Betula pubescens, quercetin, diosquinone from Diospyros tricolor, chloroform extract of Angelica sinensis root significantly induced cell death even in p53 mutated cell lines [29, 132, 164, 220]. Interestingly, administration of Withaferin A, curcumin, Angelica sinensis root chloroform extract, Ardipusilloside 1 and berberine significantly reduced the tumor volume and increased the overall survival in an orthotopic GBM animal model [199, 201, 220, 224, 237], suggesting that these compounds may cross the BBB. Natural compounds resveratrol, curcumin, eckol and Korean natural medicine recipe MSC500, significantly eradicated the CSC population in GBM [258, 259, 263, 266] and decreased the in vivo tumor growth in mice xenografts [266]. Most chemotherapy trials have failed in GBM patients, due partly to the poor penetration of drugs through the BBB. Natural products may modify the BBB permeability by altering the function of its components. In particular, procyanidine extracted from Pinus massoniana, was found to inhibit P-gp and increased the therapeutic efficacy of adriamycin by allowing it to permeate the BBB in nude mice, increasing their overall survival [281].

The few clinical trials evaluating the use of natural products for GBM have been relatively underpowered. Galactoside-specific lectin from mistletoe (ML-1) plant extract has immunoprotective/immunostimulatory activity [285-287]. Addition of ML-1 to the standard treatment for grades III and IV astrocytoma patients significantly increased the overall survival $(20.05 \pm 3.5 \mathrm{Vs} 9.90 \pm 2.1$ months) [288]. Patupilone (epothilone B), a microtubulestabilizing natural cytotoxic compound with BBB permeation and long half-life displayed progression free survival in recurrent GBM patients [289, 290].

As summarized here, a wealth of preclinical data exists to support further study using natural products in GBM. This dismal prognosis demands that we explore alternative therapy to improve outcomes for these patients. Prospective randomized clinical trials must be done to explore the use of adjunctive natural therapy in better targeting resistance and synergistically improving upon standard treatments.

\section{Abbreviations}

ALDH: Aldehyde dehydrogenase; BBB: Blood Brain Barrier; BBTB: BBB of tumors; CDKs: Cyclindependent kinases; CNS: Central Nervous System; CRT: Chemo-radiation Therapy; CSCs: Cancer Stem Cells; CT: Chemotherapy; ECM: Extracellular matrix; ER: Endoplasmic reticulum; ERK: Extracellular signalregulated kinase; GBM: Glioblastoma; GFAP: Glial Fibrillary Acidic Protein; Hsp-27- Heat shock protein 27; HIF-1 $\alpha$ : Hypoxia Inducible Factor 1 alpha; HO-1: Hemeoxygenase-1; IL-6 - Interleukin - 6; JAK: Janus Kinase; LGR5: leucine-rich repeat containing G-protein coupled receptor 5; LPS: Lipopolysaccharide; MAPK: Mitogen Activated Protein Kinase; MDR: Multidrug resistance; MGMT: O6-methylguanine-DNA methyl transferase; miRNAs: MicroRNAs; MMP: Mitochondrial Membrane Potential; MMPs: Matrix metalloproteinases; NPC: Nuclear Pore Complex; Nrf2: Nuclear Factor (erythroid-derived 2) like 2; OS: Overall survival; P-gp: P-glycoprotein; PI3K- phosphoinositide 3-kinase; PVN: Perivascular niche; RIP: Ribosome Inactivating Proteins; ROS: Reactive Oxygen Species; RT: Radiotherapy; RTK: Receptor Tyrosine kinase; STAT-3: Signal Transducer and Activator of Transcription- 3; TGF- $\beta 1$ : Transforming growth factor - $\beta 1$; TJ: Tight Junction; TMZ: Temozolomide; VEGF: Vascular Endothelial Growth Factor; XIAP: X-linked inhibitor of apoptosis protein. 


\section{ACKNOWLEDGMENTS}

The authors on this manuscript are, in parts, supported by the grants from the National Institutes of Health (P30 CA036727) and Dr. Raghupathy Vengoji is supported by the Fred and Pamela Buffet Cancer Center, University of Nebraska Medical Center, Omaha, NE.

\section{CONFLICTS OF INTEREST}

The authors have no conflicts of interest.

\section{REFERENCES}

1. McNeill KA. Epidemiology of Brain Tumors. Neurol Clin. 2016; 34:981-98.

2. Ostrom QT, Gittleman H, Fulop J, Liu M, Blanda R, Kromer C, Wolinsky Y, Kruchko C, Barnholtz-Sloan JS. CBTRUS Statistical Report: Primary Brain and Central Nervous System Tumors Diagnosed in the United States in 2008-2012. Neuro Oncol. 2015; 17:iv1-iv62.

3. Stupp R, Mason WP, van den Bent MJ, Weller M, Fisher B, Taphoorn MJ, Belanger K, Brandes AA, Marosi C, Bogdahn U, Curschmann J, Janzer RC, Ludwin SK, et al. Radiotherapy plus concomitant and adjuvant temozolomide for glioblastoma. N Engl J Med. 2005; 352:987-96.

4. Perry JR, Laperriere N, O'Callaghan CJ, Brandes AA, Menten J, Phillips C, Fay M, Nishikawa R, Cairncross JG, Roa W, Osoba D, Rossiter JP, Sahgal A, et al. Short-Course Radiation plus Temozolomide in Elderly Patients with Glioblastoma. N Engl J Med. 2017; 376:1027-37.

5. Elliott PJ, Hayward NJ, Huff MR, Nagle TL, Black KL, Bartus RT. Unlocking the blood-brain barrier: a role for RMP-7 in brain tumor therapy. Exp Neurol. 1996; 141:214-24.

6. Mann J. Natural products in cancer chemotherapy: past, present and future. Nat Rev Cancer. 2002; 2:143-8.

7. Schacter L. Etoposide phosphate: what, why, where, and how? Semin Oncol. 1996; 23:1-7.

8. Altmann KH, Gertsch J. Anticancer drugs from nature-natural products as a unique source of new microtubulestabilizing agents. Nat Prod Rep. 2007; 24:327-57.

9. Touat M, Idbaih A, Sanson M, Ligon KL. Glioblastoma targeted therapy: updated approaches from recent biological insights. Ann Oncol. 2017; 28:1457-72.

10. Parsons DW, Jones S, Zhang X, Lin JC, Leary RJ, Angenendt P, Mankoo P, Carter H, Siu IM, Gallia GL, Olivi A, McLendon R, Rasheed BA, et al. An integrated genomic analysis of human glioblastoma multiforme. Science. 2008; 321:1807-12.

11. Haas-Kogan DA, Kogan SS, Yount G, Hsu J, Haas M, Deen DF, Israel MA. p53 function influences the effect of fractionated radiotherapy on glioblastoma tumors. Int J Radiat Oncol Biol Phys. 1999; 43:399-403.
12. Dorigo O, Turla ST, Lebedeva S, Gjerset RA. Sensitization of rat glioblastoma multiforme to cisplatin in vivo following restoration of wild-type p53 function. J Neurosurg. 1998; 88:535-40.

13. Uzzaman M, Keller G, Germano IM. Enhanced proapoptotic effects of tumor necrosis factor-related apoptosis-inducing ligand on temozolomide-resistant glioma cells. J Neurosurg. 2007; 106:646-51.

14. Wang X, Chen JX, Liu JP, You C, Liu YH, Mao Q. Gain of function of mutant TP53 in glioblastoma: prognosis and response to temozolomide. Ann Surg Oncol. 2014; 21:1337-44.

15. Kaina B, Christmann M, Naumann S, Roos WP. MGMT: key node in the battle against genotoxicity, carcinogenicity and apoptosis induced by alkylating agents. DNA Repair (Amst). 2007; 6:1079-99.

16. Park CK, Kim JE, Kim JY, Song SW, Kim JW, Choi SH, Kim TM, Lee SH, Kim IH, Park SH. The Changes in MGMT Promoter Methylation Status in Initial and Recurrent Glioblastomas. Transl Oncol. 2012; 5:393-7.

17. Weller M, Felsberg J, Hartmann C, Berger H, Steinbach JP, Schramm J, Westphal M, Schackert G, Simon M, Tonn JC, Heese O, Krex D, Nikkhah G, et al. Molecular predictors of progression-free and overall survival in patients with newly diagnosed glioblastoma: a prospective translational study of the German Glioma Network. J Clin Oncol. 2009; 27:5743-50.

18. Gurrieri L, De Carlo E, Gerratana L, De Maglio G, Macerelli M, Pisa FE, Masiero E, Aprile G, Follador A, Puglisi F, Fasola G, Rizzato S, Pizzolitto S. MGMT pyrosequencing-based cut-off methylation level and clinical outcome in patients with glioblastoma multiforme. Future Oncol. 2018; 14:699-707.

19. Verbeek B, Southgate TD, Gilham DE, Margison GP. O6-Methylguanine-DNA methyltransferase inactivation and chemotherapy. Br Med Bull. 2008; 85:17-33.

20. Hong DS, Angelo LS, Kurzrock R. Interleukin-6 and its receptor in cancer: implications for translational therapeutics. Cancer. 2007; 110:1911-28.

21. Chang CY, Li MC, Liao SL, Huang YL, Shen CC, Pan HC. Prognostic and clinical implication of IL-6 expression in glioblastoma multiforme. J Clin Neurosci. 2005; 12:930-3.

22. Rahaman SO, Harbor PC, Chernova O, Barnett GH, Vogelbaum MA, Haque SJ. Inhibition of constitutively active Stat 3 suppresses proliferation and induces apoptosis in glioblastoma multiforme cells. Oncogene. 2002; 21:8404-13.

23. Bischoff SC. Quercetin: potentials in the prevention and therapy of disease. Curr Opin Clin Nutr Metab Care. 2008; 11:733-40.

24. Perez-Vizcaino F, Duarte J, Andriantsitohaina R. Endothelial function and cardiovascular disease: effects of quercetin and wine polyphenols. Free Radic Res. 2006; 40:1054-65. 
25. Chen SF, Nieh S, Jao SW, Liu CL, Wu CH, Chang YC, Yang CY, Lin YS. Quercetin suppresses drug-resistant spheres via the p38 MAPK-Hsp27 apoptotic pathway in oral cancer cells. PLoS One. 2012; 7:e49275.

26. Russo M, Palumbo R, Tedesco I, Mazzarella G, Russo P, Iacomino G, Russo GL. Quercetin and anti-CD95(Fas/ Apo1) enhance apoptosis in HPB-ALL cell line. FEBS Lett. 1999; 462:322-8.

27. Michaud-Levesque J, Bousquet-Gagnon N, Beliveau R. Quercetin abrogates IL-6/STAT3 signaling and inhibits glioblastoma cell line growth and migration. Exp Cell Res. 2012; 318:925-35.

28. Sang DP, Li RJ, Lan Q. Quercetin sensitizes human glioblastoma cells to temozolomide in vitro via inhibition of Hsp27. Acta Pharmacol Sin. 2014; 35:832-8.

29. Kim H, Moon JY, Ahn KS, Cho SK. Quercetin induces mitochondrial mediated apoptosis and protective autophagy in human glioblastoma U373MG cells. Oxid Med Cell Longev. 2013; 2013:596496.

30. Zamin LL, Filippi-Chiela EC, Vargas J, Demartini DR, Meurer L, Souza AP, Bonorino C, Salbego C, Lenz G. Quercetin promotes glioma growth in a rat model. Food Chem Toxicol. 2014; 63:205-11.

31. Jang M, Cai L, Udeani GO, Slowing KV, Thomas CF, Beecher CW, Fong HH, Farnsworth NR, Kinghorn AD, Mehta RG, Moon RC, Pezzuto JM. Cancer chemopreventive activity of resveratrol, a natural product derived from grapes. Science. 1997; 275:218-20.

32. Huang $\mathrm{H}$, Lin $\mathrm{H}$, Zhang $\mathrm{X}$, Li J. Resveratrol reverses temozolomide resistance by downregulation of MGMT in T98G glioblastoma cells by the NF-kappaB-dependent pathway. Oncol Rep. 2012; 27:2050-6.

33. Yuan Y, Xue X, Guo RB, Sun XL, Hu G. Resveratrol enhances the antitumor effects of temozolomide in glioblastoma via ROS-dependent AMPK-TSC-mTOR signaling pathway. CNS Neurosci Ther. 2012; 18:536-46.

34. Chen Y, Huang JH, Ning Y, Shen ZY. [Icariin and its pharmaceutical efficacy: research progress of molecular mechanism]. Zhong Xi Yi Jie He Xue Bao. 2011; 9:1179-84.

35. Zhang DC, Liu JL, Ding YB, Xia JG, Chen GY. Icariin potentiates the antitumor activity of gemcitabine in gallbladder cancer by suppressing NF-kappaB. Acta Pharmacol Sin. 2013; 34:301-8.

36. Li F, Gong QH, Wu Q, Lu YF, Shi JS. Icariin isolated from Epimedium brevicornum Maxim attenuates learning and memory deficits induced by d-galactose in rats. Pharmacol Biochem Behav. 2010; 96:301-5.

37. Yang L, Wang Y, Guo H, Guo M. Synergistic Anti-Cancer Effects of Icariin and Temozolomide in Glioblastoma. Cell Biochem Biophys. 2015; 71:1379-85.

38. Takamizawa J, Konishi H, Yanagisawa K, Tomida S, Osada H, Endoh H, Harano T, Yatabe Y, Nagino M, Nimura Y, Mitsudomi T, Takahashi T. Reduced expression of the let-7 microRNAs in human lung cancers in association with shortened postoperative survival. Cancer Res. 2004; 64:3753-6.

39. Dahiya N, Sherman-Baust CA, Wang TL, Davidson B, Shih Ie M, Zhang Y, Wood W 3rd, Becker KG, Morin PJ. MicroRNA expression and identification of putative miRNA targets in ovarian cancer. PLoS One. 2008; 3:e2436.

40. O'Hara AJ, Wang L, Dezube BJ, Harrington WJ Jr, Damania B, Dittmer DP. Tumor suppressor microRNAs are underrepresented in primary effusion lymphoma and Kaposi sarcoma. Blood. 2009; 113:5938-41.

41. Sugimura K, Miyata H, Tanaka K, Hamano R, Takahashi T, Kurokawa Y, Yamasaki M, Nakajima K, Takiguchi S, Mori M, Doki Y. Let-7 expression is a significant determinant of response to chemotherapy through the regulation of IL-6/STAT3 pathway in esophageal squamous cell carcinoma. Clin Cancer Res. 2012; 18:5144-53.

42. Tezcan G, Tunca B, Bekar A, Yalcin M, Sahin S, Budak F, Cecener G, Egeli U, Demir C, Guvenc G, Yilmaz G, Erkan LG, Malyer H, et al. Ficus carica latex prevents invasion through induction of let-7d expression in GBM cell lines. Cell Mol Neurobiol. 2015; 35:175-87.

43. Markiewicz-Zukowska R, Borawska MH, Fiedorowicz A, Naliwajko SK, Sawicka D, Car H. Propolis changes the anticancer activity of temozolomide in U87MG human glioblastoma cell line. BMC Complement Altern Med. 2013; 13:50.

44. Kujumgiev A, Tsvetkova I, Serkedjieva Y, Bankova V, Christov R, Popov S. Antibacterial, antifungal and antiviral activity of propolis of different geographic origin. J Ethnopharmacol. 1999; 64:235-40.

45. Silici S, Unlu M, Vardar-Unlu G. Antibacterial activity and phytochemical evidence for the plant origin of Turkish propolis from different regions. World J Microbiol Biotechnol. 2007; 23:1797-803.

46. Chen MJ, Chang WH, Lin CC, Liu CY, Wang TE, Chu CH, Shih SC, Chen YJ. Caffeic acid phenethyl ester induces apoptosis of human pancreatic cancer cells involving caspase and mitochondrial dysfunction. Pancreatology. 2008; 8:566-76.

47. Nomura M, Kaji A, Ma W, Miyamoto K, Dong Z. Suppression of cell transformation and induction of apoptosis by caffeic acid phenethyl ester. Mol Carcinog. 2001; 31:83-9.

48. Chen CN, Hsiao CJ, Lee SS, Guh JH, Chiang PC, Huang CC, Huang WJ. Chemical modification and anticancer effect of prenylated flavanones from Taiwanese propolis. Nat Prod Res. 2012; 26:116-24.

49. Borges KS, Brassesco MS, Scrideli CA, Soares AE, Tone LG. Antiproliferative effects of Tubi-bee propolis in glioblastoma cell lines. Genet Mol Biol. 2011; 34:310-4.

50. Fukushima $T$, Kawaguchi $M$, Yorita $K$, Tanaka $H$, Takeshima H, Umezawa K, Kataoka H. Antitumor effect of dehydroxymethylepoxyquinomicin, a small molecule inhibitor of nuclear factor-kappaB, on glioblastoma. Neuro Oncol. 2012; 14:19-28. 
51. Kane LP, Shapiro VS, Stokoe D, Weiss A. Induction of NF-kappaB by the Akt/PKB kinase. Curr Biol. 1999; 9:601-4.

52. Romashkova JA, Makarov SS. NF-kappaB is a target of AKT in anti-apoptotic PDGF signalling. Nature. 1999; 401:86-90.

53. Grogan PT, Sarkaria JN, Timmermann BN, Cohen MS. Oxidative cytotoxic agent withaferin A resensitizes temozolomide-resistant glioblastomas via MGMT depletion and induces apoptosis through Akt/mTOR pathway inhibitory modulation. Invest New Drugs. 2014; 32:604-17.

54. Chautard E, Loubeau G, Tchirkov A, Chassagne J, VermotDesroches C, Morel L, Verrelle P. Akt signaling pathway: a target for radiosensitizing human malignant glioma. Neuro Oncol. 2010; 12:434-43.

55. Li HF, Kim JS, Waldman T. Radiation-induced Akt activation modulates radioresistance in human glioblastoma cells. Radiat Oncol. 2009; 4:43.

56. Yang L, Liu Y, Wang M, Qian Y, Dai X, Zhu Y, Chen J, Guo S, Hisamitsu T. Celastrus orbiculatus extract triggers apoptosis and autophagy via PI3K/Akt/mTOR inhibition in human colorectal cancer cells. Oncol Lett. 2016; 12:3771-8.

57. Zhu Y, Liu Y, Qian Y, Dai X, Yang L, Chen J, Guo S, Hisamitsu T. Research on the efficacy of Celastrus Orbiculatus in suppressing TGF-beta1-induced epithelialmesenchymal transition by inhibiting HSP27 and TNFalpha-induced NF-kappa B/Snail signaling pathway in human gastric adenocarcinoma. BMC Complement Altern Med. 2014; 14:433.

58. Zhu YD, Liu YQ, Qian YY, Zhang H, Li GQ, Yang L. Extracts of Celastrus orbiculatus exhibit anti-proliferative and anti-invasive effects on human gastric adenocarcinoma cells. Chin J Integr Med. 2014.

59. Gu H, Feng J, Wang H, Qian Y, Yang L, Chen J, Jin F, Shi Y, Lu S, Liu Y. Celastrus orbiculatus extract inhibits the migration and invasion of human glioblastoma cells in vitro. BMC Complement Altern Med. 2016; 16:387.

60. Zheng ZY. Pharmacokinetic studies on 3H-andrographolide. Chinese Herbal Medicines. 1982; 13:33-6.

61. Li Y, Zhang P, Qiu F, Chen L, Miao C, Li J, Xiao W, $\mathrm{Ma}$ E. Inactivation of $\mathrm{PI} \mathrm{K} / \mathrm{Akt}$ signaling mediates proliferation inhibition and $\mathrm{G} 2 / \mathrm{M}$ phase arrest induced by andrographolide in human glioblastoma cells. Life Sci. 2012; 90:962-7.

62. Sunil C, Duraipandiyan V, Agastian P, Ignacimuthu S. Antidiabetic effect of plumbagin isolated from Plumbago zeylanica L. root and its effect on GLUT4 translocation in streptozotocin-induced diabetic rats. Food Chem Toxicol. 2012; 50:4356-63.

63. Kumar S, Gautam S, Sharma A. Antimutagenic and antioxidant properties of plumbagin and other naphthoquinones. Mutat Res. 2013; 755:30-41.

64. Luo P, Wong YF, Ge L, Zhang ZF, Liu Y, Liu L, Zhou H. Anti-inflammatory and analgesic effect of plumbagin through inhibition of nuclear factor-kappaB activation. J Pharmacol Exp Ther. 2010; 335:735-42.

65. Chen MB, Zhang Y, Wei MX, Shen W, Wu XY, Yao C, Lu $\mathrm{PH}$. Activation of AMP-activated protein kinase (AMPK) mediates plumbagin-induced apoptosis and growth inhibition in cultured human colon cancer cells. Cell Signal. 2013; 25:1993-2002.

66. Hafeez BB, Jamal MS, Fischer JW, Mustafa A, Verma AK. Plumbagin, a plant derived natural agent inhibits the growth of pancreatic cancer cells in in vitro and in vivo via targeting EGFR, Stat3 and NF-kappaB signaling pathways. Int J Cancer. 2012; 131:2175-86.

67. Kawiak A, Zawacka-Pankau J, Lojkowska E. Plumbagin induces apoptosis in Her2-overexpressing breast cancer cells through the mitochondrial-mediated pathway. J Nat Prod. 2012; 75:747-51.

68. Khaw AK, Sameni S, Venkatesan S, Kalthur G, Hande MP. Plumbagin alters telomere dynamics, induces DNA damage and cell death in human brain tumour cells. Mutat Res Genet Toxicol Environ Mutagen. 2015; 793:86-95.

69. Corn BW, Yousem DM, Scott CB, Rotman M, Asbell SO, Nelson DF, Martin L, Curran WJ Jr. White matter changes are correlated significantly with radiation dose. Observations from a randomized dose-escalation trial for malignant glioma (Radiation Therapy Oncology Group 83-02). Cancer. 1994; 74:2828-35.

70. Parthipan M, Aravindhan V, Rajendran A. Medico-botanical study of Yercaud hills in the eastern Ghats of Tamil Nadu, India. Anc Sci Life. 2011; 30:104-9.

71. Saha S, Ghosh S. Tinospora cordifolia: One plant, many roles. Anc Sci Life. 2012; 31:151-9.

72. Sharma V, Pandey D. Protective Role of Tinospora cordifolia against Lead-induced Hepatotoxicity. Toxicol Int. $2010 ; 17: 12-7$.

73. Thippeswamy G, Sheela ML, Salimath BP. Octacosanol isolated from Tinospora cordifolia downregulates VEGF gene expression by inhibiting nuclear translocation of $\mathrm{NF}-<$ kappa $>\mathrm{B}$ and its DNA binding activity. Eur $\mathrm{J}$ Pharmacol. 2008; 588:141-50.

74. Singh N, Singh SM, Shrivastava P. Effect of Tinospora cordifolia on the antitumor activity of tumor-associated macrophages-derived dendritic cells. Immunopharmacol Immunotoxicol. 2005; 27:1-14.

75. Adhvaryu MR, Reddy N, Parabia MH. Anti-tumor activity of four Ayurvedic herbs in Dalton lymphoma ascites bearing mice and their short-term in vitro cytotoxicity on DLA-cellline. Afr J Tradit Complement Altern Med. 2008; 5:409-18.

76. Prince PS, Kamalakkannan N, Menon VP. Restoration of antioxidants by ethanolic Tinospora cordifolia in alloxaninduced diabetic Wistar rats. Acta Pol Pharm. 2004; 61:283-7.

77. Desai VR, Ramkrishnan R, Chintalwar GJ, Sainis KB. G1-4A, an immunomodulatory polysaccharide from Tinospora cordifolia, modulates macrophage responses and 
protects mice against lipopolysaccharide induced endotoxic shock. Int Immunopharmacol. 2007; 7:1375-86.

78. Rao SK, Rao PS. Alteration in the radiosensitivity of HeLa cells by dichloromethane extract of guduchi (Tinospora cordifolia). Integr Cancer Ther. 2010; 9:378-84.

79. Rao SK, Rao PS, Rao BN. Preliminary investigation of the radiosensitizing activity of guduchi (Tinospora cordifolia) in tumor-bearing mice. Phytother Res. 2008; 22:1482-9.

80. Mishra R, Kaur G. Aqueous ethanolic extract of Tinospora cordifolia as a potential candidate for differentiation based therapy of glioblastomas. PLoS One. 2013; 8:e78764.

81. Abdali K, Jahed L, Amooee S, Zarshenas M, Tabatabaee H, Bekhradi R. Comparison of the Effect of Vaginal Zataria multiflora Cream and Oral Metronidazole Pill on Results of Treatments for Vaginal Infections including Trichomoniasis and Bacterial Vaginosis in Women of Reproductive Age. Biomed Res Int. 2015; 2015:683640.

82. Hosseinimehr SJ, Mahmoudzadeh A, Ahmadi A, Ashrafi SA, Shafaghati N, Hedayati N. The radioprotective effect of Zataria multiflora against genotoxicity induced by gamma irradiation in human blood lymphocytes. Cancer Biother Radiopharm. 2011; 26:325-9.

83. Dadashi M, Hashemi A, Eslami G, Fallah F, Goudarzi H, Erfanimanesh S, Taherpour A. Evaluation of antibacterial effects of Zataria multi fl ora Boiss extracts against ESBLproducing Klebsiella pneumoniae strains. Avicenna J Phytomed. 2016; 6:336-43.

84. Kavoosi G, Teixeira da Silva JA, Saharkhiz MJ. Inhibitory effects of Zataria multiflora essential oil and its main components on nitric oxide and hydrogen peroxide production in lipopolysaccharide-stimulated macrophages. J Pharm Pharmacol. 2012; 64:1491-500.

85. Sajed H, Sahebkar A, Iranshahi M. Zataria multiflora Boiss. (Shirazi thyme) — an ancient condiment with modern pharmaceutical uses. J Ethnopharmacol. 2013; 145:686-98.

86. Aghamohammadi A, Hosseinimehr SJ, Ghasemi A, Azadbakht M, Pourfallah TA. Radiosensitization Effects of a Zataria multiflora Extract on Human Glioblastoma Cells. Asian Pac J Cancer Prev. 2015; 16:7285-90.

87. Sun X, Xu R, Deng Y, Cheng H, Ma J, Ji J, Zhou Y. Effects of tetrandrine on apoptosis and radiosensitivity of nasopharyngeal carcinoma cell line CNE. Acta Biochim Biophys Sin (Shanghai). 2007; 39:869-78.

88. Ma JW, Zhang Y, Ye JC, Li R, Wen YL, Huang JX, Zhong XY. Tetrandrine Exerts a Radiosensitization Effect on Human Glioma through Inhibiting Proliferation by Attenuating ERK Phosphorylation. Biomol Ther (Seoul). 2017; 25:186-93.

89. Furnari FB, Fenton T, Bachoo RM, Mukasa A, Stommel JM, Stegh A, Hahn WC, Ligon KL, Louis DN, Brennan C, Chin L, DePinho RA, Cavenee WK. Malignant astrocytic glioma: genetics, biology, and paths to treatment. Genes Dev. 2007; 21:2683-710.
90. Wojton J, Meisen WH, Kaur B. How to train glioma cells to die: molecular challenges in cell death. J Neurooncol. 2016; 126:377-84.

91. Strik H, Deininger M, Streffer J, Grote E, Wickboldt J, Dichgans J, Weller M, Meyermann R. BCL-2 family protein expression in initial and recurrent glioblastomas: modulation by radiochemotherapy. J Neurol Neurosurg Psychiatry. 1999; 67:763-8.

92. Gilani SA, Kikuchi A, Shinwari ZK, Khattak ZI, Watanabe KN. Phytochemical, pharmacological and ethnobotanical studies of Rhazya stricta Decne. Phytother Res. 2007; 21:301-7.

93. Mukhopadhyay S, Handy GA, Funayama S, Cordell GA. Anticancer indole alkaloids of Rhazya stricta. J Nat Prod. 1981; 44:696-700.

94. Elkady AI. Crude alkaloid extract of Rhazya stricta inhibits cell growth and sensitizes human lung cancer cells to cisplatin through induction of apoptosis. Genet Mol Biol. 2013; 36:12-21.

95. Chahar MK, Sharma N, Dobhal MP, Joshi YC. Flavonoids: A versatile source of anticancer drugs. Pharmacogn Rev. 2011; 5:1-12.

96. Ramos S. Effects of dietary flavonoids on apoptotic pathways related to cancer chemoprevention. J Nutr Biochem. 2007; 18:427-42.

97. Elkady AI, Hussein RA, Abu-Zinadah OA. Effects of crude extracts from medicinal herbs Rhazya stricta and Zingiber officinale on growth and proliferation of human brain cancer cell line in vitro. Biomed Res Int. 2014; 2014:260210.

98. Zhou GB, Chen SJ, Wang ZY, Chen Z. Back to the future of oridonin: again, compound from medicinal herb shows potent antileukemia efficacies in vitro and in vivo. Cell Res. 2007; 17:274-6.

99. Li D, Wu LJ, Tashiro S, Onodera S, Ikejima T. Oridonin inhibited the tyrosine kinase activity and induced apoptosis in human epidermoid carcinoma A431 cells. Biol Pharm Bull. 2007; 30:254-60.

100. Lin TY, Lee CC, Chen KC, Lin CJ, Shih CM. Inhibition of RNA transportation induces glioma cell apoptosis via downregulation of RanGAP1 expression. Chem Biol Interact. 2015; 232:49-57.

101. Ming LG, Zhou J, Cheng GZ, Ma HP, Chen KM. Osthol, a coumarin isolated from common cnidium fruit, enhances the differentiation and maturation of osteoblasts in vitro. Pharmacology. 2011; 88:33-43.

102. You L, Feng S, An R, Wang X. Osthole: a promising lead compound for drug discovery from a traditional Chinese medicine (TCM). Nat Prod Commun. 2009; 4:297-302.

103. Wang R, Kong J, Wang D, Lien LL, Lien EJ. A survey of Chinese herbal ingredients with liver protection activities. Chin Med. 2007; 2:5.

104. Lin K, Gao Z, Shang B, Sui S, Fu Q. Osthole suppresses the proliferation and accelerates the apoptosis of human glioma cells via the upregulation of microRNA-16 
and downregulation of MMP-9. Mol Med Rep. 2015; 12:4592-7.

105. Asuthkar S, Velpula KK, Chetty C, Gorantla B, Rao JS. Epigenetic regulation of miRNA-211 by MMP-9 governs glioma cell apoptosis, chemosensitivity and radiosensitivity. Oncotarget. 2012; 3:1439-54. https://doi.org/10.18632/ oncotarget.683.

106. Lakka SS, Rajan M, Gondi C, Yanamandra N, Chandrasekar N, Jasti SL, Adachi Y, Siddique K, Gujrati M, Olivero W, Dinh DH, Kouraklis G, Kyritsis AP, et al. Adenovirus-mediated expression of antisense MMP-9 in glioma cells inhibits tumor growth and invasion. Oncogene. 2002; 21:8011-9.

107. Chetty C, Lakka SS, Bhoopathi P, Gondi CS, Veeravalli KK, Fassett D, Klopfenstein JD, Dinh DH, Gujrati M, Rao JS. Urokinase plasminogen activator receptor and/or matrix metalloproteinase-9 inhibition induces apoptosis signaling through lipid rafts in glioblastoma xenograft cells. Mol Cancer Ther. 2010; 9:2605-17.

108. Chen JC, Chiu MH, Nie RL, Cordell GA, Qiu SX. Cucurbitacins and cucurbitane glycosides: structures and biological activities. Nat Prod Rep. 2005; 22:386-99.

109. Blaskovich MA, Sun J, Cantor A, Turkson J, Jove R, Sebti SM. Discovery of JSI-124 (cucurbitacin I), a selective Janus kinase/signal transducer and activator of transcription 3 signaling pathway inhibitor with potent antitumor activity against human and murine cancer cells in mice. Cancer Res. $2003 ; 63: 1270-9$

110. Duncan KL, Duncan MD, Alley MC, Sausville EA. Cucurbitacin E-induced disruption of the actin and vimentin cytoskeleton in prostate carcinoma cells. Biochem Pharmacol. 1996; 52:1553-60.

111. Sun J, Blaskovich MA, Jove R, Livingston SK, Coppola D, Sebti SM. Cucurbitacin Q: a selective STAT3 activation inhibitor with potent antitumor activity. Oncogene. 2005; $24: 3236-45$.

112. Jayaprakasam B, Seeram NP, Nair MG. Anticancer and antiinflammatory activities of cucurbitacins from Cucurbita andreana. Cancer Lett. 2003; 189:11-6.

113. Yin D, Wakimoto N, Xing H, Lu D, Huynh T, Wang X, Black KL, Koeffler HP. Cucurbitacin B markedly inhibits growth and rapidly affects the cytoskeleton in glioblastoma multiforme. Int J Cancer. 2008; 123:1364-75.

114. Andres-Lacueva C, Shukitt-Hale B, Galli RL, Jauregui O, Lamuela-Raventos RM, Joseph JA. Anthocyanins in aged blueberry-fed rats are found centrally and may enhance memory. Nutr Neurosci. 2005; 8:111-20.

115. Abdullah Thani NA, Sallis B, Nuttall R, Schubert FR, Ahsan M, Davies D, Purewal S, Cooper A, Rooprai HK. Induction of apoptosis and reduction of MMP gene expression in the U373 cell line by polyphenolics in Aronia melanocarpa and by curcumin. Oncol Rep. 2012; 28:1435-42.
116. Khan M, Yu B, Rasul A, Al Shawi A, Yi F, Yang H, Ma T. Jaceosidin Induces Apoptosis in U87 Glioblastoma Cells through G2/M Phase Arrest. Evid Based Complement Alternat Med. 2012; 2012:703034.

117. Sha O, Niu J, Ng TB, Cho EY, Fu X, Jiang W. Anti-tumor action of trichosanthin, a type 1 ribosome-inactivating protein, employed in traditional Chinese medicine: a mini review. Cancer Chemother Pharmacol. 2013; 71:1387-93.

118. Miao J, Jiang Y, Wang D, Zhou J, Fan C, Jiao F, Liu B, Zhang J, Wang Y, Zhang Q. Trichosanthin suppresses the proliferation of glioma cells by inhibiting LGR5 expression and the Wnt/beta-catenin signaling pathway. Oncol Rep. 2015; 34:2845-52.

119. Nakata S, Campos B, Bageritz J, Bermejo JL, Becker N, Engel F, Acker T, Momma S, Herold-Mende C, Lichter P, Radlwimmer B, Goidts V. LGR5 is a marker of poor prognosis in glioblastoma and is required for survival of brain cancer stem-like cells. Brain Pathol. 2013; 23:60-72.

120. Chang HF, Huang WT, Chen HJ, Yang LL. Apoptotic effects of gamma-mangostin from the fruit hull of Garcinia mangostana on human malignant glioma cells. Molecules. 2010; 15:8953-66.

121. Matsumoto K, Akao Y, Ohguchi K, Ito T, Tanaka T, Iinuma M, Nozawa Y. Xanthones induce cell-cycle arrest and apoptosis in human colon cancer DLD-1 cells. Bioorg Med Chem. 2005; 13:6064-9.

122. Shoieb AM, Elgayyar M, Dudrick PS, Bell JL, Tithof PK. In vitro inhibition of growth and induction of apoptosis in cancer cell lines by thymoquinone. Int J Oncol. 2003; 22:107-13.

123. Gurung RL, Lim SN, Khaw AK, Soon JF, Shenoy K, Mohamed Ali S, Jayapal M, Sethu S, Baskar R, Hande MP. Thymoquinone induces telomere shortening, DNA damage and apoptosis in human glioblastoma cells. PLoS One. 2010; 5:e12124.

124. Al-Majed AA, Al-Omar FA, Nagi MN. Neuroprotective effects of thymoquinone against transient forebrain ischemia in the rat hippocampus. Eur J Pharmacol. 2006; 543:40-7.

125. Racoma IO, Meisen WH, Wang QE, Kaur B, Wani AA. Thymoquinone inhibits autophagy and induces cathepsinmediated, caspase-independent cell death in glioblastoma cells. PLoS One. 2013; 8:e72882.

126. Torres MP, Ponnusamy MP, Chakraborty S, Smith LM, Das S, Arafat HA, Batra SK. Effects of thymoquinone in the expression of mucin 4 in pancreatic cancer cells: implications for the development of novel cancer therapies. Mol Cancer Ther. 2010; 9:1419-31.

127. Lee DY, Lee MK, Kim GS, Noh HJ, Lee MH. Brazilin inhibits growth and induces apoptosis in human glioblastoma cells. Molecules. 2013; 18:2449-57.

128. Ehrhardt H, Fulda S, Fuhrer M, Debatin KM, Jeremias I. Betulinic acid-induced apoptosis in leukemia cells. Leukemia. 2004; 18:1406-12. 
129. Jung GR, Kim KJ, Choi CH, Lee TB, Han SI, Han HK, Lim SC. Effect of betulinic acid on anticancer drug-resistant colon cancer cells. Basic Clin Pharmacol Toxicol. 2007; 101:277-85.

130. Kessler JH, Mullauer FB, de Roo GM, Medema JP. Broad in vitro efficacy of plant-derived betulinic acid against cell lines derived from the most prevalent human cancer types. Cancer Lett. 2007; 251:132-45.

131. Schmidt ML, Kuzmanoff KL, Ling-Indeck L, Pezzuto JM. Betulinic acid induces apoptosis in human neuroblastoma cell lines. Eur J Cancer. 1997; 33:2007-10.

132. Wick W, Grimmel C, Wagenknecht B, Dichgans J, Weller M. Betulinic acid-induced apoptosis in glioma cells: A sequential requirement for new protein synthesis, formation of reactive oxygen species, and caspase processing. J Pharmacol Exp Ther. 1999; 289:1306-12.

133. Fulda S, Jeremias I, Steiner HH, Pietsch T, Debatin KM. Betulinic acid: a new cytotoxic agent against malignant brain-tumor cells. Int J Cancer. 1999; 82:435-41.

134. Guerram M, Jiang ZZ, Sun L, Zhu X, Zhang LY. Antineoplastic effects of deoxypodophyllotoxin, a potent cytotoxic agent of plant origin, on glioblastoma U-87 MG and SF126 cells. Pharmacol Rep. 2015; 67:245-52.

135. Rao VS, Rao A, Karanth KS. Anticonvulsant and neurotoxicity profile of Nardostachys jatamansi in rats. $\mathrm{J}$ Ethnopharmacol. 2005; 102:351-6.

136. Ahmad M, Yousuf S, Khan MB, Hoda MN, Ahmad AS, Ansari MA, Ishrat T, Agrawal AK, Islam F. Attenuation by Nardostachys jatamansi of 6-hydroxydopamine-induced parkinsonism in rats: behavioral, neurochemical, and immunohistochemical studies. Pharmacol Biochem Behav. 2006; 83:150-60.

137. Kapoor H, Yadav N, Chopra M, Mahapatra SC, Agrawal V. Strong Anti-tumorous Potential of Nardostachys jatamansi Rhizome Extract on Glioblastoma and In Silico Analysis of its Molecular Drug Targets. Curr Cancer Drug Targets. 2017; 17:74-88.

138. Malumbres M, Barbacid M. Cell cycle, CDKs and cancer: a changing paradigm. Nat Rev Cancer. 2009; 9:153-66.

139. Ueki K, Ono Y, Henson JW, Efird JT, von Deimling A, Louis DN. CDKN2/p16 or RB alterations occur in the majority of glioblastomas and are inversely correlated. Cancer Res. 1996; 56:150-3.

140. Franco LH, Joffe EB, Puricelli L, Tatian M, Seldes AM, Palermo JA. Indole alkaloids from the tunicate Aplidium meridianum. J Nat Prod. 1998; 61:1130-2.

141. Bettayeb K, Tirado OM, Marionneau-Lambot S, Ferandin Y, Lozach O, Morris JC, Mateo-Lozano S, Drueckes P, Schachtele C, Kubbutat MH, Liger F, Marquet B, Joseph B, et al. Meriolins, a new class of cell death inducing kinase inhibitors with enhanced selectivity for cyclin-dependent kinases. Cancer Res. 2007; 67:8325-34.

142. Jarry M, Lecointre C, Malleval C, Desrues L, Schouft MT, Lejoncour V, Liger F, Lyvinec G, Joseph B, Loaec N,
Meijer L, Honnorat J, Gandolfo P, et al. Impact of meriolins, a new class of cyclin-dependent kinase inhibitors, on malignant glioma proliferation and neo-angiogenesis. Neuro Oncol. 2014; 16:1484-98.

143. Kuete V, Nguemeving JR, Beng VP, Azebaze AG, Etoa FX, Meyer M, Bodo B, Nkengfack AE. Antimicrobial activity of the methanolic extracts and compounds from Vismia laurentii De Wild (Guttiferae). J Ethnopharmacol. 2007; 109:372-9.

144. Akao Y, Nakagawa Y, Iinuma M, Nozawa Y. Anti-cancer effects of xanthones from pericarps of mangosteen. Int $\mathrm{J}$ Mol Sci. 2008; 9:355-70.

145. Kuete V. Potential of Cameroonian plants and derived products against microbial infections: a review. Planta Med. 2010; 76:1479-91.

146. Kuete V, Sandjo LP, Ouete JL, Fouotsa H, Wiench B, Efferth T. Cytotoxicity and modes of action of three naturally occurring xanthones (8-hydroxycudraxanthone G, morusignin I and cudraxanthone I) against sensitive and multidrug-resistant cancer cell lines. Phytomedicine. 2014; 21:315-22.

147. Chea A, Hout S, Long C, Marcourt L, Faure R, Azas N, Elias R. Antimalarial activity of sesquiterpene lactones from Vernonia cinerea. Chem Pharm Bull (Tokyo). 2006; 54:1437-9.

148. Pratheeshkumar P, Kuttan G. Effect of vernolide-A, a sesquiterpene lactone from Vernonia cinerea $\mathrm{L}$, on cell-mediated immune response in B16F-10 metastatic melanoma-bearing mice. Immunopharmacol Immunotoxicol. 2011; 33:533-8.

149. Jain SP, Puri HS. Ethnomedicinal plants of Jaunsar-Bawar hills, Uttar Pradesh, India. J Ethnopharmacol. 1984; 12:213-22.

150. Youn UJ, Miklossy G, Chai X, Wongwiwatthananukit S, Toyama O, Songsak T, Turkson J, Chang LC. Bioactive sesquiterpene lactones and other compounds isolated from Vernonia cinerea. Fitoterapia. 2014; 93:194-200.

151. Hu X, Lin S, Yu D, Qiu S, Zhang X, Mei R. A preliminary study: the anti-proliferation effect of salidroside on different human cancer cell lines. Cell Biol Toxicol. 2010; 26:499-507.

152. Zhang Y, Yao Y, Wang H, Guo Y, Zhang H, Chen L. Effects of salidroside on glioma formation and growth inhibition together with improvement of tumor microenvironment. Chin J Cancer Res. 2013; 25:520-6.

153. Mora MC, Bassa LM, Wong KE, Tirabassi MV, Arenas RB, Schneider SS. Rhodiola crenulata inhibits Wnt/beta-catenin signaling in glioblastoma. J Surg Res. 2015; 197:247-55.

154. Ferrara N, Davis-Smyth T. The biology of vascular endothelial growth factor. Endocr Rev. 1997; 18:4-25.

155. Freitas S, Costa S, Azevedo C, Carvalho G, Freire S, Barbosa P, Velozo E, Schaer R, Tardy M, Meyer R, Nascimento I. Flavonoids inhibit angiogenic cytokine 
production by human glioma cells. Phytother Res. 2011; 25:916-21.

156. Dixit S. Anticancer Effect of Rutin Isolated from the Methanolic Extract of Triticum aestivum Straw in Mice. Med Sci. 2014; 2:153-60.

157. Lauterwein M, Oethinger M, Belsner K, Peters T, Marre R. In vitro activities of the lichen secondary metabolites vulpinic acid, (+)-usnic acid, and (-)-usnic acid against aerobic and anaerobic microorganisms. Antimicrob Agents Chemother. 1995; 39:2541-3.

158. Ogmundsdottir HM, Zoega GM, Gissurarson SR, Ingolfsdottir K. Anti-proliferative effects of lichen-derived inhibitors of 5-lipoxygenase on malignant cell-lines and mitogen-stimulated lymphocytes. J Pharm Pharmacol. 1998; 50:107-15.

159. Bezivin C, Tomasi S, Lohezic-Le Devehat F, Boustie J. Cytotoxic activity of some lichen extracts on murine and human cancer cell lines. Phytomedicine. 2003; 10:499-503.

160. Emsen B, Aslan A, Togar B, Turkez H. In vitro antitumor activities of the lichen compounds olivetoric, physodic and psoromic acid in rat neuron and glioblastoma cells. Pharm Biol. 2016; 54:1748-62.

161. Lee JC, Kim HR, Kim J, Jang YS. Antioxidant property of an ethanol extract of the stem of Opuntia ficus-indica var. saboten. J Agric Food Chem. 2002; 50:6490-6.

162. Goldstein G, Nobel PS. Water Relations and LowTemperature Acclimation for Cactus Species Varying in Freezing Tolerance. Plant Physiol. 1994; 104:675-81.

163. Hahm SW, Park J, Son YS. Opuntia humifusa partitioned extracts inhibit the growth of U87MG human glioblastoma cells. Plant Foods Hum Nutr. 2010; 65:247-52.

164. Adeniyi BA, Robert MF, Chai H, Fong HH. In vitro cytotoxicity activity of Diosquinone, a naphthoquinone epoxide. Phytother Res. 2003; 17:282-4.

165. Salvesen GS, Duckett CS. IAP proteins: blocking the road to death's door. Nat Rev Mol Cell Biol. 2002; 3:401-10.

166. Skagias L, Politi E, Karameris A, Sambaziotis D, Archondakis A, Ntinis A, Moreas I, Vasou O, Koutselini H, Patsouris E. Survivin expression as a strong indicator of recurrence in urothelial bladder cancer. Predictive value of nuclear versus cytoplasmic staining. Anticancer Res. 2009; 29:4163-7.

167. Roca H, Varsos Z, Pienta KJ. CCL2 protects prostate cancer PC3 cells from autophagic death via phosphatidylinositol 3-kinase/AKT-dependent survivin up-regulation. J Biol Chem. 2008; 283:25057-73.

168. Altieri DC. The case for survivin as a regulator of microtubule dynamics and cell-death decisions. Curr Opin Cell Biol. 2006; 18:609-15.

169. Gu JQ, Gills JJ, Park EJ, Mata-Greenwood E, Hawthorne ME, Axelrod F, Chavez PI, Fong HH, Mehta RG, Pezzuto JM, Kinghorn AD. Sesquiterpenoids from Tithonia diversifolia with potential cancer chemopreventive activity. J Nat Prod. 2002; 65:532-6.

170. Liao MH, Lin WC, Wen HC, Pu HF. Tithonia diversifolia and its main active component tagitinin $\mathrm{C}$ induce survivin inhibition and G2/M arrest in human malignant glioblastoma cells. Fitoterapia. 2011; 82:331-41.

171. Lim KJ, Rajan K, Eberhart CG. Effects of Zeng Sheng Ping/ ACAPHA on malignant brain tumor growth and Notch signaling. Anticancer Res. 2012; 32:2689-96.

172. Brennan C, Momota H, Hambardzumyan D, Ozawa T, Tandon A, Pedraza A, Holland E. Glioblastoma subclasses can be defined by activity among signal transduction pathways and associated genomic alterations. PLoS One. 2009; 4:e7752.

173. Chen J, Kesari S, Rooney C, Strack PR, Chen J, Shen H, $\mathrm{Wu}$ L, Griffin JD. Inhibition of notch signaling blocks growth of glioblastoma cell lines and tumor neurospheres. Genes Cancer. 2010; 1:822-35. https://doi. org/10.1177/1947601910383564.

174. Kanamori M, Kawaguchi T, Nigro JM, Feuerstein BG, Berger MS, Miele L, Pieper RO. Contribution of Notch signaling activation to human glioblastoma multiforme. J Neurosurg. 2007; 106:417-27.

175. Purow BW, Haque RM, Noel MW, Su Q, Burdick MJ, Lee J, Sundaresan T, Pastorino S, Park JK, Mikolaenko I, Maric D, Eberhart CG, Fine HA. Expression of Notch-1 and its ligands, Delta-like-1 and Jagged-1, is critical for glioma cell survival and proliferation. Cancer Res. 2005; 65:2353-63.

176. Fan X. [Inhibitory effect of antitumor-B and retinamide on precancerous lesions of the bladder in rats]. [Article in Chinese]. Zhongguo Yi Xue Ke Xue Yuan Xue Bao. 1993; $15: 71-3$

177. Sun Z, Guan X, Li N, Liu X, Chen X. Chemoprevention of oral cancer in animal models, and effect on leukoplakias in human patients with ZengShengPing, a mixture of medicinal herbs. Oral Oncol. 2010; 46:105-10.

178. Zhang Z, Wang Y, Yao R, Li J, Yan Y, La Regina M, Lemon WL, Grubbs CJ, Lubet RA, You M. Cancer chemopreventive activity of a mixture of Chinese herbs (antitumor B) in mouse lung tumor models. Oncogene. 2004; 23:3841-50.

179. Lin P, Zhang J, Rong Z, Han R, Xu S, Gao R, Ding Z, Wang J, Feng H, Cao S. Studies on medicamentous inhibitory therapy for esophageal precancerous lesions--3and 5-year inhibitory effects of antitumor-B, retinamide and riboflavin. Proc Chin Acad Med Sci Peking Union Med Coll. 1990; 5:121-9.

180. Ding Z, Gao F, Lin P. [Long-term effect of treating patients with precancerous lesions of the esophagus]. Zhonghua Zhong Liu Za Zhi. 1999; 21:275-7.

181. Hou J, Lin PZ, Chen ZF, Ding ZW, Li SS, Men FS, Guo LP, He YT, Qiao CY, Guo CL, Duan JP, Wen DG. Field population-based blocking treatment of esophageal epithelia dysplasia. World J Gastroenterol. 2002; 8:418-22. 
182. Dissanayake AA, Bejcek BE, Zhang CR, Nair MG. Sesquiterpenoid Lactones in Tanacetum huronense Inhibit Human Glioblastoma Cell Proliferation. Nat Prod Commun. 2016; 11:579-82.

183. Guo L, Wang LH, Sun B, Yang JY, Zhao YQ, Dong YX, Spranger MI, Wu CF. Direct in vivo evidence of protective effects of grape seed procyanidin fractions and other antioxidants against ethanol-induced oxidative DNA damage in mouse brain cells. J Agric Food Chem. 2007; 55:5881-91

184. Zheng HL, Yang J, Hou Y, Sun B, Zhang Q, Mou Y, Wand L, Wu C. Oligomer procyanidins (F2) isolated from grape seeds inhibits tumor angiogenesis and cell invasion by targeting HIF-1alpha in vitro. Int J Oncol. 2015; 46:708-20.

185. Zhang FJ, Yang JY, Mou YH, Sun BS, Ping YF, Wang JM, Bian XW, Wu CF. Inhibition of U-87 human glioblastoma cell proliferation and formyl peptide receptor function by oligomer procyanidins (F2) isolated from grape seeds. Chem Biol Interact. 2009; 179:419-29.

186. Frederich M, Marcowycz A, Cieckiewicz E, Megalizzi V, Angenot L, Kiss R. In vitro anticancer potential of tree extracts from the Walloon Region forest. Planta Med. 2009; 75:1634-7.

187. Ismail AM, Musa AM, Nasir T, Magaji MG, Jega YA, Ibrahim I. Anti-proliferative study and isolation of Ochnaflavone from the ethyl acetate-soluble fraction of Ochna kibbiensis Hutch \& Dalziel. Nat Prod Res. 2017; 31:2149-52.

188. Fiore G, Nencini C, Cavallo F, Capasso A, Bader A, Giorgi $\mathrm{G}$, Micheli L. In vitro antiproliferative effect of six Salvia species on human tumor cell lines. Phytother Res. 2006; 20:701-3.

189. Mbosso Teinkela JE, Assob Nguedia JC, Meyer F, Vouffo Donfack E, Lenta Ndjakou B, Ngouela S, Tsamo E, Adiogo D, Guy Blaise Azebaze A, Wintjens R. In vitro antimicrobial and anti-proliferative activities of plant extracts from Spathodea campanulata, Ficus bubu, and Carica papaya. Pharm Biol. 2016; 54:1086-95.

190. Niazi F, Drevs J, Diergarten K, Dorn A, Maier A, Fiebig HH, Bruyns E, Scheele J. AMT: preclinical pharmacology studies. Int J Oncol. 2009; 34:1341-52.

191. West DB, Iakougova O, Olsson C, Ross D, Ohmen J, Chatterjee A. Mouse genetics/genomics: an effective approach for drug target discovery and validation. Med Res Rev. 2000; 20:216-30.

192. Durg S, Dhadde SB, Vandal R, Shivakumar BS, Charan CS. Withania somnifera (Ashwagandha) in neurobehavioural disorders induced by brain oxidative stress in rodents: a systematic review and meta-analysis. J Pharm Pharmacol. 2015; 67:879-99.

193. Dar NJ, Hamid A, Ahmad M. Pharmacologic overview of Withania somnifera, the Indian Ginseng. Cell Mol Life Sci. 2015; 72:4445-60.
194. Mirjalili MH, Moyano E, Bonfill M, Cusido RM, Palazon J. Steroidal lactones from Withania somnifera, an ancient plant for novel medicine. Molecules. 2009; 14:2373-93.

195. Vanden Berghe W, Sabbe L, Kaileh M, Haegeman G, Heyninck K. Molecular insight in the multifunctional activities of Withaferin A. Biochem Pharmacol. 2012; 84:1282-91.

196. Sun GY, Li R, Cui J, Hannink M, Gu Z, Fritsche KL, Lubahn DB, Simonyi A. Withania somnifera and Its Withanolides Attenuate Oxidative and Inflammatory Responses and Up-Regulate Antioxidant Responses in BV-2 Microglial Cells. Neuromolecular Med. 2016; 18:241-52.

197. Shah N, Kataria H, Kaul SC, Ishii T, Kaur G, Wadhwa R. Effect of the alcoholic extract of Ashwagandha leaves and its components on proliferation, migration, and differentiation of glioblastoma cells: combinational approach for enhanced differentiation. Cancer Sci. 2009; 100:1740-7.

198. Kataria H, Kumar S, Chaudhary H, Kaur G. Withania somnifera Suppresses Tumor Growth of Intracranial Allograft of Glioma Cells. Mol Neurobiol. 2016; 53:4143-58.

199. Santagata S, Xu YM, Wijeratne EM, Kontnik R, Rooney C, Perley CC, Kwon H, Clardy J, Kesari S, Whitesell L, Lindquist S, Gunatilaka AA. Using the heat-shock response to discover anticancer compounds that target protein homeostasis. ACS Chem Biol. 2012; 7:340-9.

200. Duvoix A, Blasius R, Delhalle S, Schnekenburger M, Morceau F, Henry E, Dicato M, Diederich M. Chemopreventive and therapeutic effects of curcumin. Cancer Lett. 2005; 223:181-90.

201. Perry MC, Demeule M, Regina A, Moumdjian R, Beliveau R. Curcumin inhibits tumor growth and angiogenesis in glioblastoma xenografts. Mol Nutr Food Res. 2010; 54:1192-201.

202. Anand P, Kunnumakkara AB, Newman RA, Aggarwal BB. Bioavailability of curcumin: problems and promises. Mol Pharm. 2007; 4:807-18.

203. Suresh D, Srinivasan K. Tissue distribution \& elimination of capsaicin, piperine \& curcumin following oral intake in rats. Indian J Med Res. 2010; 131:682-91.

204. Ramachandran C, Resek AP, Escalon E, Aviram A, Melnick SJ. Potentiation of gemcitabine by Turmeric Force in pancreatic cancer cell lines. Oncol Rep. 2010; 23:1529-35.

205. Ramachandran C, Nair SM, Escalon E, Melnick SJ. Potentiation of etoposide and temozolomide cytotoxicity by curcumin and turmeric force in brain tumor cell lines. $\mathrm{J}$ Complement Integr Med. 2012; 9:Article 20.

206. Ji M, Choi J, Lee J, Lee Y. Induction of apoptosis by ar-turmerone on various cell lines. Int J Mol Med. 2004; 14:253-6.

207. Ramachandran C, Quirin KW, Escalon EA, Lollett IV, Melnick SJ. Therapeutic Effect of Supercritical $\mathrm{CO}_{2}$ 
Extracts of Curcuma Species with Cancer Drugs in Rhabdomyosarcoma Cell Lines. Phytother Res. 2015; 29:1152-60.

208. Ramachandran C, Portalatin G, Quirin KW, Escalon E, Khatib Z, Melnick SJ. Inhibition of AKT signaling by supercritical CO2 extract of mango ginger (Curcuma amada Roxb.) in human glioblastoma cells. J Complement Integr Med. 2015; 12:307-15.

209. Bellacosa A, Kumar CC, Di Cristofano A, Testa JR. Activation of AKT kinases in cancer: implications for therapeutic targeting. Adv Cancer Res. 2005; 94:29-86.

210. Hanahan D, Weinberg RA. The hallmarks of cancer. Cell. 2000; 100:57-70.

211. Arlt A, Gehrz A, Muerkoster S, Vorndamm J, Kruse ML, Folsch UR, Schafer H. Role of NF-kappaB and Akt/ $\mathrm{PI} 3 \mathrm{~K}$ in the resistance of pancreatic carcinoma cell lines against gemcitabine-induced cell death. Oncogene. 2003; $22: 3243-51$

212. Cheng JQ, Jiang X, Fraser M, Li M, Dan HC, Sun M, Tsang BK. Role of X-linked inhibitor of apoptosis protein in chemoresistance in ovarian cancer: possible involvement of the phosphoinositide-3 kinase/Akt pathway. Drug Resist Updat. 2002; 5:131-46.

213. Falasca M. PI3K/Akt signalling pathway specific inhibitors: a novel strategy to sensitize cancer cells to anti-cancer drugs. Curr Pharm Des. 2010; 16:1410-6.

214. Whang YE, Yuan XJ, Liu Y, Majumder S, Lewis TD. Regulation of sensitivity to TRAIL by the PTEN tumor suppressor. Vitam Horm. 2004; 67:409-26.

215. Downward J. PI 3-kinase, Akt and cell survival. Semin Cell Dev Biol. 2004; 15:177-82.

216. Ye YN, Koo MW, Li Y, Matsui H, Cho CH. Angelica sinensis modulates migration and proliferation of gastric epithelial cells. Life Sci. 2001; 68:961-8.

217. Ye YN, Liu ES, Li Y, So HL, Cho CC, Sheng HP, Lee SS, Cho $\mathrm{CH}$. Protective effect of polysaccharides-enriched fraction from Angelica sinensis on hepatic injury. Life Sci. 2001; 69:637-46.

218. Ye YN, Liu ES, Shin VY, Koo MW, Li Y, Wei EQ, Matsui $\mathrm{H}$, Cho $\mathrm{CH}$. A mechanistic study of proliferation induced by Angelica sinensis in a normal gastric epithelial cell line. Biochem Pharmacol. 2001; 61:1439-48.

219. Ye YN, So HL, Liu ES, Shin VY, Cho CH. Effect of polysaccharides from Angelica sinensis on gastric ulcer healing. Life Sci. 2003; 72:925-32.

220. Tsai NM, Lin SZ, Lee CC, Chen SP, Su HC, Chang WL, Harn HJ. The antitumor effects of Angelica sinensis on malignant brain tumors in vitro and in vivo. Clin Cancer Res. 2005; 11:3475-84.

221. Xiong J, Cheng G, Tang H, Zhen HN, Zhang X. Ardipusilloside I induces apoptosis in human glioblastoma cells through a caspase-8-independent FasL/Fas-signaling pathway. Environ Toxicol Pharmacol. 2009; 27:264-70.
222. Wang R, Xiao X, Wang PY, Wang L, Guan Q, Du C, Wang XJ. Stimulation of autophagic activity in human glioma cells by anti-proliferative ardipusilloside I isolated from Ardisia pusilla. Life Sci. 2014; 110:15-22.

223. Wang XJ, Cui H, Wang R, Huan ML, Zhang BL, Zhang WD, Teng ZH, Gan HQ, Zhou SY, Gu Y. Metabolism and pharmacokinetic study of ardipusilloside $I$ in rats. Planta Med. 2012; 78:565-74.

224. Dang H, Wang J, Cheng JX, Wang PY, Wang Y, Cheng LF, Du C, Wang XJ. Efficacy of local delivery of ardipusilloside I using biodegradable implants against cerebral tumor growth. Am J Cancer Res. 2015; 5:243-54.

225. Fang XF, Cui ZJ. The anti-botulism triterpenoid toosendanin elicits calcium increase and exocytosis in rat sensory neurons. Cell Mol Neurobiol. 2011; 31:1151-62.

226. Shi YL, Li MF. Biological effects of toosendanin, a triterpenoid extracted from Chinese traditional medicine. Prog Neurobiol. 2007; 82:1-10.

227. Tang MZ, Wang ZF, Shi YL. Involvement of cytochrome c release and caspase activation in toosendanin-induced PC12 cell apoptosis. Toxicology. 2004; 201:31-8.

228. Zhang B, Wang ZF, Tang MZ, Shi YL. Growth inhibition and apoptosis-induced effect on human cancer cells of toosendanin, a triterpenoid derivative from chinese traditional medicine. Invest New Drugs. 2005; 23:547-53.

229. Cao L, Qu D, Wang H, Zhang S, Jia C, Shi Z, Wang Z, Zhang J, Ma J. Toosendanin Exerts an Anti Cancer Effect in Glioblastoma by Inducing Estrogen Receptor beta- and p53-Mediated Apoptosis. Int J Mol Sci. 2016; 17:1928.

230. Lazennec G. Estrogen receptor beta, a possible tumor suppressor involved in ovarian carcinogenesis. Cancer Lett. 2006; 231:151-7.

231. Treeck O, Lattrich C, Springwald A, Ortmann O. Estrogen receptor beta exerts growth-inhibitory effects on human mammary epithelial cells. Breast Cancer Res Treat. 2010; 120:557-65.

232. Mantena SK, Sharma SD, Katiyar SK. Berberine, a natural product, induces G1-phase cell cycle arrest and caspase3 -dependent apoptosis in human prostate carcinoma cells. Mol Cancer Ther. 2006; 5:296-308.

233. Sun Y, Xun K, Wang Y, Chen X. A systematic review of the anticancer properties of berberine, a natural product from Chinese herbs. Anticancer Drugs. 2009; 20:757-69.

234. Satou T, Akao N, Matsuhashi R, Koike K, Fujita K, Nikaido $\mathrm{T}$. Inhibitory effect of isoquinoline alkaloids on movement of second-stage larvae of Toxocara canis. Biol Pharm Bull. 2002; 25:1651-4.

235. Singhal KC. Anthelmintic activity of berberine hydrochloride against Syphacia obvelata in mice. Indian J Exp Biol. 1976; 14:345-7.

236. Eom KS, Kim HJ, So HS, Park R, Kim TY. Berberineinduced apoptosis in human glioblastoma T98G cells is mediated by endoplasmic reticulum stress accompanying reactive oxygen species and mitochondrial dysfunction. Biol Pharm Bull. 2010; 33:1644-9. 
237. Liu Q, Xu X, Zhao M, Wei Z, Li X, Zhang X, Liu Z, Gong Y, Shao C. Berberine induces senescence of human glioblastoma cells by downregulating the EGFR-MEK-ERK signaling pathway. Mol Cancer Ther. 2015; 14:355-63.

238. Li J, Tang H, Zhang Y, Tang C, Li B, Wang Y, Gao Z, Luo P, Yin A, Wang X, Cheng G, Fei Z. Saponin 1 induces apoptosis and suppresses NF-kappaB-mediated survival signaling in glioblastoma multiforme (GBM). PLoS One. 2013; 8:e81258.

239. Wang Y, Tang H, Zhang Y, Li J, Li B, Gao Z, Wang X, Cheng G, Fei Z. Saponin B, a novel cytostatic compound purified from Anemone taipaiensis, induces apoptosis in a human glioblastoma cell line. Int J Mol Med. 2013; 32:1077-84.

240. Ji CC, Tang HF, Hu YY, Zhang Y, Zheng MH, Qin HY, Li SZ, Wang XY, Fei Z, Cheng G. Saponin 6 derived from Anemone taipaiensis induces U87 human malignant glioblastoma cell apoptosis via regulation of Fas and $\mathrm{Bcl} 2$ family proteins. Mol Med Rep. 2016; 14:380-6.

241. Wang X, Zhang W, Gao K, Lu Y, Tang H, Sun X. Oleananetype saponins from Anemone taipaiensis and their cytotoxic activities. Fitoterapia. 2013; 89:224-30.

242. Kim KS, Jung Yang H, Lee IS, Kim KH, Park J, Jeong HS, Kim Y, Ahn KS, Na YC, Jang HJ. The aglycone of ginsenoside $\mathrm{Rg} 3$ enables glucagon-like peptide-1 secretion in enteroendocrine cells and alleviates hyperglycemia in type 2 diabetic mice. Sci Rep. 2015; 5:18325.

243. Kim YJ, Zhang D, Yang DC. Biosynthesis and biotechnological production of ginsenosides. Biotechnol Adv. 2015; 33:717-35.

244. Sun C, Yu Y, Wang L, Wu B, Xia L, Feng F, Ling Z, Wang S. Additive antiangiogenesis effect of ginsenoside $\mathrm{Rg} 3$ with low-dose metronomic temozolomide on rat glioma cells both in vivo and in vitro. J Exp Clin Cancer Res. 2016; 35:32.

245. Dean M, Fojo T, Bates S. Tumour stem cells and drug resistance. Nat Rev Cancer. 2005; 5:275-84.

246. Mannino M, Chalmers AJ. Radioresistance of glioma stem cells: intrinsic characteristic or property of the 'microenvironment-stem cell unit'? Mol Oncol. 2011; 5:374-86.

247. Nakai E, Park K, Yawata T, Chihara T, Kumazawa A, Nakabayashi H, Shimizu K. Enhanced MDR1 expression and chemoresistance of cancer stem cells derived from glioblastoma. Cancer Invest. 2009; 27:901-8.

248. Sharma A, Shiras A. Cancer stem cell-vascular endothelial cell interactions in glioblastoma. Biochem Biophys Res Commun. 2016; 473:688-92.

249. Calabrese C, Poppleton H, Kocak M, Hogg TL, Fuller C, Hamner B, Oh EY, Gaber MW, Finklestein D, Allen M, Frank A, Bayazitov IT, Zakharenko SS, et al. A perivascular niche for brain tumor stem cells. Cancer Cell. 2007; 11:69-82.

250. Galan-Moya EM, Le Guelte A, Lima Fernandes E, Thirant C, Dwyer J, Bidere N, Couraud PO, Scott MG, Junier MP, Chneiweiss H, Gavard J. Secreted factors from brain endothelial cells maintain glioblastoma stem-like cell expansion through the mTOR pathway. EMBO Rep. 2011; 12:470-6.

251. Liu H, Patel MR, Prescher JA, Patsialou A, Qian D, Lin J, Wen S, Chang YF, Bachmann MH, Shimono Y, Dalerba P, Adorno M, Lobo N, et al. Cancer stem cells from human breast tumors are involved in spontaneous metastases in orthotopic mouse models. Proc Natl Acad Sci U S A. 2010; 107:18115-20.

252. Zhu TS, Costello MA, Talsma CE, Flack CG, Crowley JG, Hamm LL, He X, Hervey-Jumper SL, Heth JA, Muraszko KM, DiMeco F, Vescovi AL, Fan X. Endothelial cells create a stem cell niche in glioblastoma by providing $\mathrm{NOTCH}$ ligands that nurture self-renewal of cancer stem-like cells. Cancer Res. 2011; 71:6061-72.

253. Borovski T, Beke P, van Tellingen O, Rodermond HM, Verhoeff JJ, Lascano V, Daalhuisen JB, Medema JP, Sprick MR. Therapy-resistant tumor microvascular endothelial cells contribute to treatment failure in glioblastoma multiforme. Oncogene. 2013; 32:1539-48.

254. Efferth T. Stem cells, cancer stem-like cells, and natural products. Planta Med. 2012; 78:935-42.

255. Yao CJ, Lai GM, Yeh CT, Lai MT, Shih PH, Chao WJ, Whang-Peng J, Chuang SE, Lai TY. Honokiol Eliminates Human Oral Cancer Stem-Like Cells Accompanied with Suppression of Wnt/ beta -Catenin Signaling and Apoptosis Induction. Evid Based Complement Alternat Med. 2013; 2013:146136.

256. Yao CJ, Yeh CT, Lee LM, Chuang SE, Yeh CF, Chao WJ, Lai TY, Lai GM. Elimination of cancer stem-like "side population" cells in hepatoma cell lines by chinese herbal mixture "tien-hsien liquid". Evid Based Complement Alternat Med. 2012; 2012:617085.

257. Sengupta R, Barone A, Marasa J, Taylor S, Jackson E, Warrington NM, Rao S, Kim AH, Leonard JR, PiwnicaWorms D, Rubin JB. Novel chemical library screen identifies naturally occurring plant products that specifically disrupt glioblastoma-endothelial cell interactions. Oncotarget. 2015; 6:18282-92. https://doi.org/10.18632/oncotarget.4957.

258. Yao CJ, Han TY, Shih PH, Yi TY, Lai IC, Chang KH, Lai TY, Chang CL, Lai GM. Elimination of cancer stem-like side population in human glioblastoma cells accompanied with stemness gene suppression by Korean herbal recipe MSC500. Integr Cancer Ther. 2014; 13:541-54.

259. Fong D, Yeh A, Naftalovich R, Choi TH, Chan MM. Curcumin inhibits the side population (SP) phenotype of the rat C6 glioma cell line: towards targeting of cancer stem cells with phytochemicals. Cancer Lett. 2010; 293:65-72.

260. Sachdeva M, Mo YY. miR-145-mediated suppression of cell growth, invasion and metastasis. Am J Transl Res. 2010; 2:170-80.

261. Tahmasebi Mirgani M, Isacchi B, Sadeghizadeh M, Marra F, Bilia AR, Mowla SJ, Najafi F, Babaei E. Dendrosomal 
curcumin nanoformulation downregulates pluripotency genes via miR-145 activation in U87MG glioblastoma cells. Int J Nanomedicine. 2014; 9:403-17.

262. Yang YP, Chien Y, Chiou GY, Cherng JY, Wang ML, Lo WL, Chang YL, Huang PI, Chen YW, Shih YH, Chen MT, Chiou SH. Inhibition of cancer stem cell-like properties and reduced chemoradioresistance of glioblastoma using microRNA145 with cationic polyurethane-short branch PEI. Biomaterials. 2012; 33:1462-76.

263. Jiao Y, Li H, Liu Y, Guo A, Xu X, Qu X, Wang S, Zhao J, Li Y, Cao Y. Resveratrol Inhibits the Invasion of Glioblastoma-Initiating Cells via Down-Regulation of the PI3K/Akt/NF-kappaB Signaling Pathway. Nutrients. 2015; 7:4383-402.

264. Kang KA, Lee KH, Chae S, Zhang R, Jung MS, Lee Y, Kim SY, Kim HS, Joo HG, Park JW, Ham YM, Lee NH, Hyun JW. Eckol isolated from Ecklonia cava attenuates oxidative stress induced cell damage in lung fibroblast cells. FEBS Lett. 2005; 579:6295-304.

265. Kim KC, Kang KA, Zhang R, Piao MJ, Kim GY, Kang MY, Lee SJ, Lee NH, Surh YJ, Hyun JW. Up-regulation of Nrf2-mediated heme oxygenase-1 expression by eckol, a phlorotannin compound, through activation of Erk and PI3K/Akt. Int J Biochem Cell Biol. 2010; 42:297-305.

266. Hyun KH, Yoon CH, Kim RK, Lim EJ, An S, Park MJ, Hyun JW, Suh Y, Kim MJ, Lee SJ. Eckol suppresses maintenance of stemness and malignancies in glioma stemlike cells. Toxicol Appl Pharmacol. 2011; 254:32-40.

267. Chow BW, Gu C. The molecular constituents of the bloodbrain barrier. Trends Neurosci. 2015; 38:598-608.

268. Nico B, Ribatti D. Morphofunctional aspects of the bloodbrain barrier. Curr Drug Metab. 2012; 13:50-60.

269. Schinkel AH. P-Glycoprotein, a gatekeeper in the bloodbrain barrier. Adv Drug Deliv Rev. 1999; 36:179-94.

270. Obermeier B, Daneman R, Ransohoff RM. Development, maintenance and disruption of the blood-brain barrier. Nat Med. 2013; 19:1584-96.

271. Lecuyer MA, Kebir H, Prat A. Glial influences on BBB functions and molecular players in immune cell trafficking. Biochim Biophys Acta. 2016; 1862:472-82.

272. Zhao X, Chen R, Liu M, Feng J, Chen J, Hu K. Remodeling the blood-brain barrier microenvironment by natural products for brain tumor therapy. Acta Pharm Sin B. 2017; 7:541-53.

273. van Tellingen O, Yetkin-Arik B, de Gooijer MC, Wesseling P, Wurdinger T, de Vries HE. Overcoming the blood-brain tumor barrier for effective glioblastoma treatment. Drug Resist Updat. 2015; 19:1-12.

274. Jacobs VL, Landry RP, Liu Y, Romero-Sandoval EA, De Leo JA. Propentofylline decreases tumor growth in a rodent model of glioblastoma multiforme by a direct mechanism on microglia. Neuro Oncol. 2012; 14:119-31.

275. Assimopoulou AN, Boskou D, Papageorgiou VP. Antioxidant activities of alkannin, shikonin and
Alkannatinctoria root extracts in oil substrates. Food Chemistry. 2004; 87:433-8.

276. Nam KN, Son MS, Park JH, Lee EH. Shikonins attenuate microglial inflammatory responses by inhibition of ERK, Akt, and NF-kappaB: neuroprotective implications. Neuropharmacology. 2008; 55:819-25.

277. Staniforth V, Wang SY, Shyur LF, Yang NS. Shikonins, phytocompounds from Lithospermum erythrorhizon, inhibit the transcriptional activation of human tumor necrosis factor alpha promoter in vivo. J Biol Chem. 2004; 279:5877-85.

278. Wang L, Li Z, Zhang X, Wang S, Zhu C, Miao J, Chen L, Cui L, Qiao H. Protective effect of shikonin in experimental ischemic stroke: attenuated TLR4, p-p38MAPK, NF-kappaB, TNF-alpha and MMP-9 expression, up-regulated claudin-5 expression, ameliorated BBB permeability. Neurochem Res. 2014; 39:97-106.

279. Zhang FY, Hu Y, Que ZY, Wang P, Liu YH, Wang ZH, Xue YX. Shikonin Inhibits the Migration and Invasion of Human Glioblastoma Cells by Targeting Phosphorylated beta-Catenin and Phosphorylated PI3K/Akt: A Potential Mechanism for the Anti-Glioma Efficacy of a Traditional Chinese Herbal Medicine. Int J Mol Sci. 2015; 16:23823-48.

280. Wei H, Wang S, Zhen L, Yang Q, Wu Z, Lei X, Lv J, Xiong L, Xue R. Resveratrol attenuates the blood-brain barrier dysfunction by regulation of the MMP-9/TIMP-1 balance after cerebral ischemia reperfusion in rats. J Mol Neurosci. 2015; 55:872-9.

281. He L, Zhao C, Yan M, Zhang LY, Xia YZ. Inhibition of P-glycoprotein function by procyanidine on blood-brain barrier. Phytother Res. 2009; 23:933-7.

282. Mahringer A, Karamustafa S, Klotz D, Kahl S, Konkimalla VB, Wang Y, Wang J, Liu HY, Boechzelt H, Hao X, Bauer R, Fricker G, Efferth T. Inhibition of P-glycoprotein at the blood-brain barrier by phytochemicals derived from traditional Chinese medicine. Cancer Genomics Proteomics. 2010; 7:191-205.

283. Wang YF, Gu YT, Qin GH, Zhong L, Meng YN. Curcumin ameliorates the permeability of the blood-brain barrier during hypoxia by upregulating heme oxygenase-1 expression in brain microvascular endothelial cells. J Mol Neurosci. 2013; 51:344-51.

284. Hermisson M, Klumpp A, Wick W, Wischhusen J, Nagel G, Roos W, Kaina B, Weller M. O6-methylguanine DNA methyltransferase and p53 status predict temozolomide sensitivity in human malignant glioma cells. J Neurochem. 2006; 96:766-76.

285. Lenartz D, Stoffel B, Menzel J, Beuth J. Immunoprotective activity of the galactoside-specific lectin from mistletoe after tumor destructive therapy in glioma patients. Anticancer Res. 1996; 16:3799-802.

286. Beuth J. Clinical relevance of immunoactive mistletoe lectin-I. Anticancer Drugs. 1997; 8 Suppl 1: S53-5. 
287. Bezivin C, Tomasi S, Rouaud I, Delcros JG, Boustie J. Cytotoxic activity of compounds from the lichen: Cladonia convoluta. Planta Med. 2004; 70:874-7.

288. Lenartz D, Dott U, Menzel J, Schierholz JM, Beuth J. Survival of glioma patients after complementary treatment with galactoside-specific lectin from mistletoe. Anticancer Res. 2000; 20:2073-6.

289. Oehler C, Frei K, Rushing EJ, McSheehy PM, Weber D, Allegrini PR, Weniger D, Lutolf UM, Knuth A, Yonekawa Y, Barath K, Broggini-Tenzer A, Pruschy M, et al. Patupilone (epothilone B) for recurrent glioblastoma: clinical outcome and translational analysis of a singleinstitution phase I/II trial. Oncology. 2012; 83:1-9.

290. O'Reilly T, Wartmann M, Brueggen J, Allegrini PR, Floersheimer A, Maira M, McSheehy PM. Pharmacokinetic profile of the microtubule stabilizer patupilone in tumorbearing rodents and comparison of anti-cancer activity with other MTS in vitro and in vivo. Cancer Chemother Pharmacol. 2008; 62:1045-54. 